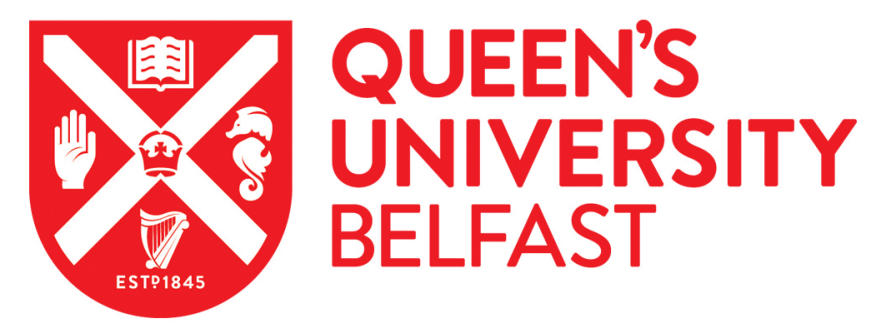

\title{
What determines voting behaviors of Muslim minorities in Europe: Muslim identity or left-right ideology?
}

Baysu, G., \& Swyngedouw, M. (2020). What determines voting behaviors of Muslim minorities in Europe: Muslim identity or left-right ideology? Political Psychology, 41(5), 837. https://doi.org/10.1111/pops.12653

\author{
Published in: \\ Political Psychology
}

Document Version:

Peer reviewed version

Queen's University Belfast - Research Portal:

Link to publication record in Queen's University Belfast Research Portal

Publisher rights

(C) 2019 International Society of Political Psychology.

This work is made available online in accordance with the publisher's policies. Please refer to any applicable terms of use of the publisher.

\section{General rights}

Copyright for the publications made accessible via the Queen's University Belfast Research Portal is retained by the author(s) and / or other copyright owners and it is a condition of accessing these publications that users recognise and abide by the legal requirements associated with these rights.

Take down policy

The Research Portal is Queen's institutional repository that provides access to Queen's research output. Every effort has been made to ensure that content in the Research Portal does not infringe any person's rights, or applicable UK laws. If you discover content in the Research Portal that you believe breaches copyright or violates any law, please contact openaccess@qub.ac.uk. 
What determines voting behaviors of Muslim minorities in Europe:

Muslim identity or left-right ideology?

Gülseli Baysu ${ }^{1} \&$ Marc Swyngedouw ${ }^{2}$

ACCEPTED FOR PUBLICATION IN POLITICAL PSYCHOLOGY ON 07.01.2020

${ }^{1}$ Queen's University of Belfast, Centre for Identity and Intergroup Relations, UK

${ }^{2}$ University of Leuven, Centre for Sociological Research, Belgium

Author Note

Correspondence concerning this article should be addressed to Dr. Gülseli Baysu, Queen's University of Belfast, School of Psychology. University Road, Belfast, BT7 1NN, Northern Ireland, United Kingdom. E-mail: g.baysu@qub.ac.uk or gulseli.baysu@ gmail.com

Funding: The data was collected with the support of the National Science Foundation FWO-Vlaanderen, the National Lottery, The KU Leuven Research council. 
Voting Behaviors of Muslim Minorities in Europe

What determines voting behaviors of Muslim minorities in Europe:

Muslim identity or left-right ideology?

\begin{abstract}
Voting is key to political integration of immigrant-background minorities, but what determines their voting preferences remains unclear. Moreover, dual-citizen minorities can vote differently in their country of residence and origin. Using a representative survey of Turkish-Muslim minorities in two cities in Belgium $\left(N=447, M \_a g e=36.3\right)$, we asked whether left-right ideology or religious identity predicted their voting in their country of residence and origin, besides typical predictors of right-wing voting (i.e., efficacy, deprivation, and authoritarianism). Authoritarianism, low political efficacy and high deprivation predicted voting for right-wing parties in Turkey, whereas the latter two, surprisingly, predicted voting for the left in Belgium. Latent class analyses of their religious practices distinguished "moderate" vs "strict" Muslims. While "strict" Muslims voted for right-wing parties in Turkey, ideology did not predict their voting. Conversely, in Belgium, while Muslim identity did not predict their voting, ideology did. Analyzing their combined effects, "moderate" Muslims voted based on their ideology_right-leaning voting for the right, whereas "strict" Muslims voted according to their interests as a disadvantaged minority in Belgium — thus voting for the left—or as a devout Muslim in Turkey - thus voting for the right. Our results elucidate processes underlying the voting behaviors of European-Muslim minorities.
\end{abstract}

Keywords: Voting, left-right ideology, Muslim identity, Muslim, Europe, social cleavage 
Muslim minorities constitute a large population in Western countries, making up more than five percent of their populations (Pew Research Center, 2017a). The prejudice against Muslims is high as they often face distrust and discrimination in Western countries (Pew Research Center, 2017b). Adding to this hostile climate, right-wing political parties mobilize people against immigrants and Muslims (Schmuck \& Matthes, 2018; Swyngedouw \& Ivalidi 2001; van der Brug \& Fennema, 2007; for the US, Kteily \& Bruneau, 2016). Accordingly, several researchers investigated psychological and political predictors of voting for (extreme) right-wing parties (e.g., Aichholzer \& Zandonella, 2016; Cornelis \& Van Hiel, 2015; van der Brug \& Fennema, 2007; Vasilopoulos et al., 2018). This research, however, was limited to majority members' voting behaviors, possibly because Muslim minorities are unlikely to vote for extreme right-wing parties. Nevertheless, it is an interesting and underresearched question why still a minority of them vote for right-wing parties in their country of residence (Clemens, 2017; Khemilat, 2017; Pew Research Center, 2017c). A separate line of research focused on immigrant political integration in Western democracies, particularly of Muslim minorities, investigating their political participation in their country of residence. These studies looked at their organizational ties and collective action tendencies (Fleischmann, Phalet \& Swyngedouw, 2013; Fleischmann, Phalet \& Klein, 2011; Just, Sandovici, \& Listhaug, 2014; Simon \& Ruhs, 2008) but not their voting behaviors (but see Kinnvall, \& Nesbitt-Larking, 2011; Kranendonk e al., 2018). Extending these separate research lines, the present research aims to investigate the voting behaviors and/or intentions (i.e., voting for right-wing versus left-wing parties) of Muslim minorities in their country of residence in a Western-European country and in their country of origin. We look at their transnational political activities in the home country, because immigrant-background Muslim minorities are entitled to have dual citizenships in many European countries, and dual citizens can vote both in their country of residence and origin (Baubock, 2005; Collyer, 2014). 
On the explanatory side, we first look at typical predictors of right-wing voting among majority populations from a social-political psychology perspective, such as authoritarianism, deprivation and (in)efficacy. We ask to what extent these predictors can explain voting behaviors of European-Muslim minorities in their country of residence and origin. Next, to explain the unique and combined effects of religious identity and left-right ideology on voting behaviors of Muslim minorities, we bridge the social-identity approach from the social psychology literature (Tajfel \& Turner, 1986) with the theory of social cleavages from the political sociology tradition (Lipset \& Rokkan, 1967). Rather than a homogenized and essentialist understanding of Muslim identity, we seek to identify qualitatively distinct ways of being Muslim, looking at various religious practices via latent class analysis. We then explore the intersectionality of Muslim identity content with left-right ideology, asking whether ideology will qualify the meaning and consequences of Muslim identity content for voting behavior. Against the background of a common representation of Islam and Muslim identity as a threat to democracy in Western media, the present research seeks to deamalgamate the Muslim identity and its political consequences. By investigating the unique and interactive effects of ideology and Muslim identity content, we thus go beyond previous research on political integration of Muslims.

We specifically focus on Turkish-Muslim minorities in Belgium for several reasons. First, Turkish-Muslim minorities constitute a large population in Europe (around 4 million). Most of these immigrants, coming from less developed rural backgrounds in Turkey, were recruited to work in unskilled jobs. Second, many emigrants maintain their Turkish citizenship, making them potential voters also in Turkey. Around 5\% of voters (2.8 million) in Turkey reside abroad, with 2.5 million in Western-Europe, and around 200000 in Belgium (Mencutek, 2015; Mencutek \& Yilmaz, 2016). Third, research evidence suggests a sharp contrast in their voting strategies as they vote for right-wing parties in Turkey (Mencutek \& 
Yilmaz, 2016) and left-wing parties in Europe, including Belgium. Despite being conservative in social issues, most Muslim minorities vote for left-wing parties in their country of residence (Dancygier, 2017). For instance, in the UK, 85\% of Muslims voted for Labour in 2017 elections (Clemens, 2017). In France, 93\% voted for Hollande, the Socialist Party candidate, in 2012 presidential elections (Khemilat, 2017). In the US, two-thirds of Muslim minorities vote for Democratic Party (Pew Research Center, 2017c).

Finally, investigating the voting behaviors of Turkish-Muslim minorities in the country of residence and origin provides a unique vantage point to understand the role of the group position and the national context. Turkish-Muslims are part of the majority in Turkey, a majority-Muslim country, whereas they have a disadvantaged minority position in WesternEurope (Verkuyten \& Yildiz, 2006). Belgium is a majority-Christian country and a secular society, where the religion of Muslim minorities is seen as a barrier to their integration (Foner \& Alba, 2008). The present research thus aims to investigate the voting strategies of TurkishMuslim minorities in Belgium and in Turkey, using a representative survey of TurkishMuslim minorities in two Belgian cities.

\section{Authoritarian attitudes, deprivation and efficacy}

From a social-political psychology perspective, authoritarianism, deprivation and efficacy play a key role in explaining collective action (van Zomeren, Postmes, \& Spear, 2008) and intergroup attitudes and prejudice (Pettigrew, 2016). These predictors are also studied in relation to voting behaviors of majority members.

Authoritarianism can be described as strict adherence to conventional values and authority, and aggression towards norm-violators (Altemeyer, 1981). It strongly predicts prejudice (Pettigrew, 2016). Beyond intergroup attitudes, it is also related to right-wing (Meloen, Van der Linden, \& De Witte, 1996) and extreme right-wing voting (Aichholzer \& Zandonella, 2016; Cornelis \& Van Hiel, 2015; Vasilopoulos et al., 2018). 
Collective/group deprivation is the belief that one's group receives less than others (Walker \& Pettigrew, 1984). People can choose to remedy this situation through conventional or unconventional political participation (such as voting and collective action, respectively). Accordingly, collective deprivation predicted increased collective action (Pettigrew, 2016; for meta-analysis, van Zomeren et al., 2008) and increased intentions to vote for a separatist party in Scotland (Abrams \& Grant, 2011), populist parties in the UK (Brexit) and US (Trump) (Marchlewska et al., 2018), and extreme right-wing parties in France (Urbanska \& Guimond, 2018). While psychological research looks at relative group deprivation or discrimination (van Zomeren et al., 2008), the political sociology tradition looks at political deprivation, i.e., the belief that one or one's group disregarded or abandoned by politics (Craig et al., 1990). Political deprivation, just like collective/group deprivation, was associated with right-wing voting (e.g., in Belgium, Swyngedouw, 2001). We looked at different measures of deprivation in this study.

As opposed to deprivation, efficacy refers to a sense of influence and effectiveness to change a group-related problem through conventional or unconventional political participation (Van Zomeren et al., 2018). Efficacy can be measured as group efficacy (i.e., the belief that one's group can change things for the better) (Van Zomeren et al., 2018) or as political efficacy (i.e., the belief that one can influence the political matters) (Craig et al., 1990; Swyngedouw, 2001). Both political efficacy (e.g., Fox \& Schofield, 1989) and group efficacy (Mummendey et al., 1999) were related to collective action (Van Zomeren et al., 2018). While we know of no research linking group efficacy to voting behavior, political inefficacy and disorientation predicted right-wing voting (Swyngedouw, 2001; Swyngedouw \& Depickere, 2007). We focused on political efficacy in this study.

In sum, those who have authoritarian attitudes, feel politically or collectively deprived and politically inefficacious tend to vote for right-wing parties (vs. left-wing parties). Given 
that most research evidence refers to majority members, we expect these predictions to hold when Turkish-Muslim Belgians vote in Turkey, where they are the majority. We do not put forward any hypotheses regarding whether these predictions would hold when they vote in Belgium, where they are a disadvantaged minority group. However, we can speculate that if the effects of these predictors do not depend on the intergroup position, they should work similarly. There is also reason to expect the opposite, though. Because the left is more likely to give disadvantaged minorities a voice (Dancygier, 2017), Muslim minority citizens who feel abandoned by and having no influence on Belgian politics could vote for left-wing parties in Belgium.

\section{Left-right ideology}

In the political sociology literature, one of the major determinants of voting is social and political cleavages in a society. According to the theory of social cleavages (Lipset \& Rokkan, 1967), a cleavage refers to a salient demographic division, such as class or religion, which is associated with party preferences. Cleavages involve different dimensions (Bartolini \& Mair 1990; Brooks, 2006). A subjective dimension refers to group identifications of voters. In parallel, parties may position themselves around the salient cleavages to attract voters.

In Europe, the left-right ideological position is historically and currently one of the most salient cleavages determining voting behavior and party positions (Lipset \& Rokkan, 1967; Van der Brug et al., 2000). The left-right ideology is thus one of the strongest predictors of (left-right) party voting in Western-Europe (Van der Brug et al., 2000; Winter, Swyngedouw \& Dumont, 2006). Although its meaning is traditionally related to socioeconomic issues/cleavages and government regulations and provisions, new cleavages or subcleavages have also emerged, for instance, with regards to socio-cultural issues. Left-right ideology can thus refer to positions of peoples or parties on either or both economic and socio-cultural issues (e.g., in Belgium, Winter et al., 2006). While its interpretation can 
change across individuals and countries (e.g., Huber \& Inglehart 1995), we see the left-right dimension as "an organizing element of the shared political consciousness of individuals in a given society" (p. 205, Kroh, 2007). In other words, even if people would not completely agree on what "left" or "right" actually means, they would agree, for instance, in their classification of parties as the left or right. The evidence regarding the within-person stability of political ideology over time suggests that left-right self-placement may be part of individuals' political predisposition (Sears \& Funk 1999). We thus focused on the left-right self-placement as a standard measure of ideology that is widely used for public opinion research, rather than individuals' specific positions on different issues (Kroh, 2007) ${ }^{1}$.

Most research evidence on left-right self-placement and voting behavior refers to majority members' positions and party preferences. It is less certain whether left-right ideology would significantly predict voting behaviors of Turkish-Muslim minorities in Belgium so that the left-leaning would vote for left-wing parties while the right-leaning would vote for right-wing parties (Main effect of ideology). Given that most right-wing parties in Western-Europe oppose Muslims and Islam (Schmuck \& Matthes, 2018), it is also possible that ideology does not significantly predict their voting behaviors, and that they would vote for left-wing parties regardless of their ideological position (No main effect of ideology).

Societies can differ in the way certain cleavages are highlighted more than others (Brooks, 2006). For instance, in the US, the liberal-conservative ideological dimension seems to be more salient, and in turn, it predicts voting (Jacoby, 2010). From the perspective of cleavage theory (Lipset \& Rokkan, 1967), religion is a salient social-political cleavage among voters in Turkey (Baysu \& Phalet, 2017; Carkoglu, 2007; Kalaycioglu, 1994). Secularist

\footnotetext{
${ }^{1}$ Although it was not our main focus, we explored how Muslim minorities' positions in specific sociocultural and socio-economic issues predicted their voting behavior as additional analyses for interested readers
} 
versus religious/pro-Islamist cleavage overlaps with Mardin's (1973) traditional center (the secularist) versus periphery (the religious) distinction in the formation of Turkish politics (Carkoglu, 2007; Kalaycioglu, 1994). Since secular vs. religious distinction is the most salient cleavage historically and currently, and the formation of left-right ideology is more recent in Turkish politics (Carkoglu, 2007), it is possible that the left-right ideology does not contribute to the explanation of voting behavior in Turkey (No main effect of ideology). It is also possible that these orientations work in parallel with the secularist vs. religious cleavage (Carkoglu, 2007). For instance, Carkoglu (2008) finds unique contributions of both ideological position and religiosity to the explanation of voting behavior in 2007 elections in Turkey, so that right-leaning and religious voters tend to vote for the conservative Justice and Development Party (AKP) (for 2011 elections, Toros, 2013). Similarly, ideology could predict voting behaviors of Turkish-Muslim Belgians in Turkey (Main effect of ideology).

In sum, for both countries, there are theoretical reasons to believe that left-right ideology could contribute significantly to the explanation of voting behaviors of TurkishMuslim Belgians but also reasons to suggest that it may fail to do so.

\section{Social Identity}

In social psychology literature, social identity is one of the main pillars of political participation. According to Social identity theory (Tajfel \& Turner, 1986), commitment to a disadvantaged group may motivate group members toward collective action targeted at social change. Accordingly, social psychological models of collective action focus on social identification as a prerequisite of collective action (van Zomeren et al., 2008; Simon \& Klandermans, 2001). The association between social identity and collective action can also be applied to explain other forms of political participation, such as voting. To understand the role of identity in voting behavior, we need to consider political parties and leaders, and their strategies of recruitment. Social identity model of leadership (Haslam, Reicher, \& Platow, 
2011) explains how a political leader can be seen as someone who shares a social identity with group members - and who attracts followers on this basis. Accordingly, leaders will be successful if they are seen as "one of us". Analyzing the Australian elections over 100 years, Steffens and Haslam (2013) found that victors of the elections made significantly more references to 'we' and 'us'. From a social-psychological perspective, thus, social identity can predict voting both from bottom-up so that individuals vote according to their salient and dominant identities, and from top-down so that leaders and political parties can affect party preferences by affirming certain identities.

Bridging social identity theory with the theory of social cleavages, cleavages also affect voting bottom-up so that individuals may identify with and vote according to salient and dominant cleavages and from top-down so that parties align and position themselves around these cleavages and thus can affect voting. Parties may target certain religious or ethnic identity groups to attract them as voters such as left-wing parties' attempts at minority recruitment (Just at al., 2014; Dickson \& Scheve, 2006). For instance, Labour party in the UK had separate seating arrangements for men and women during a rally in a Muslimconcentrated neighborhood of London. Parties may also oppose certain religious or ethnic identity groups as in the case of right-wing parties' opposition to religious and ethnic minorities. This opposition then becomes a driver of their voter potential (Schmuck \& Matthes, 2018; van der Brug \& Fennema, 2007). These will also affect party preferences of the individuals who identity with those religious and ethnic groups. Social identities based on ethnicity or religion can affect voting behavior, by offering individuals common policy preferences (Dickson \& Scheve, 2006).

Given the importance of their religious identity to Muslim minorities (Fleischmann \& Phalet, 2012), we focus on their religious identity as Muslim rather than their ethnic identity. Although their ethnic and religious identities overlap, in light of the current political and 
electoral climate surrounding issues of Islam and Muslims in Europe, we expect Muslims' religious identity to be more salient in determining their voting behavior (for other types of political participation, see Fleischman et al., 2011, Phalet, Baysu \& Verkuyten, 2010). Their religious identity as Muslim is the marker of their difference in Europe (Foner \& Alba, 2008) and of their inclusion in Turkey. Right-wing parties' opposition to Islam in Europe, or rightwing/conservative parties' endorsement of Islam in Turkey both highlight their religious identity.

\section{Religious identity and political participation}

Against the background of suspicions around Muslims' politicization (Fleischman et al., 2011), several studies looked at the relationship between Muslim identification and political participation in Europe - albeit with inconsistent results. Looking at Muslim minorities across several European countries, while Fleischmann et al. (2011) report positive associations between Muslim identification and political action for defending Islam, Just and colleagues (2014) find positive, zero and negative associations between various indicators of Muslim identity and political action. While being a Muslim predicted less political action, religiosity predicted increased political activity among second-generation Muslims. This positive association was limited to unconventional political action such as demonstrations. They found no significant associations between religiosity and institutionalized types of political action (e.g., organizational ties). Investigating voting likelihood of Muslim minorities across several European countries, Kranendonk et al. (2018) found no main effects of Muslim identification, but reported that the associations between Muslim identification and voting likelihood varied by their national identification, the extent of shard grievances, by national context and group.

Besides religious identification, several researchers studied ethnic and national identities among Muslim minorities (Simon \& Ruhs, 2008; Fleischmann et al., 2013; 
Klandermans, Van der Toorn \& Van Stekelenburg, 2008). According to the politicized identity model (Simon \& Klandermans, 2001; Simon \& Ruhs, 2008), dual ethnic and national identities predict civic engagement, while ethnic (or religious) identities predict in-group oriented political participation (e.g., among Turkish-Muslim immigrants in Germany, Simon \& Ruhs, 2008; in Belgium, Fleischmann et al., 2013). Dual identities do not always lead to higher civic engagement, however, for instance when the context does not recognize their dual identity (Verkuyten, 2017; Wiley et al. 2014). Thus we also consider ethnic and national identity, and explore the interaction of national identity with ethnic and religious identities. While voting is civic engagement in itself regardless of the party, it remains an open question whether dual identity would predict voting for left or right-wing parties. However, this is not the main focus of the paper because our focus is on the religious identity as Muslim, as an important, salient yet contested identity for Muslim minorities in Europe (Foner \& Alba, 2008).

\section{Religious identity content as Muslim}

The inconsistent findings regarding the association between Muslim identity and various political participation types could be partly due to the way Muslim identity is measured. Rather than social identity or identification, the content of social identity might be more critical for political participation (Van Zomeren et al., 2008). Therefore, rather than a homogenized understanding of Muslim identity, we focus on Muslim identity content and seek to identify qualitatively distinct ways of being Muslim by looking at their religious practices via latent class analysis. Thus, theoretically we consider the behavioral involvement as a critical dimension of religious identity content (Ashmore et al., 2004).

Phalet and colleagues (2012) looked at distinct ways of being Muslim among secondgeneration immigrants across several European countries via a similar clustering technique, and found private, selective and strict types of Muslims. While "private" Muslims are 
strongly attached to their Muslim identity with low religious practice, strict and selective Muslims have strong religious attachments, and strong or moderate religious practices, respectively. We tentatively expect to find "strict" and "moderate/secular" types in the current study, in line with the conservative vs. secular divide among Turkish-Muslims in Turkey (Baysu \& Phalet, 2017). Moreover, the present study only includes measures of religious practice, making it unlikely to find a "private" Muslim with high attachment and no religious practice (Phalet et al., 2012). Going beyond previous research, we analyze the religious practices of men and women separately because in Islam requirements for certain religious practices depend on gender (e.g., men are expected to attend mosques). This would allow us to see whether men and women engage in Islam differently.

\section{Religious identity content and voting}

To relate the religious identity content to voting, we need to revisit the social cleavage theory. In Western-Europe, the most salient social-political cleavage that determines voting among majorities is left-right ideology (Van der Brug et al., 2000; Winter et al., 2006). Although religion was once cited as an important cleavage (Lipset \& Rokkan, 1967), it referred to cleavages within the majority religion (such as the cleavage between Catholics vs Protestants, or between the church and state) and not to cleavages within Islam. Moreover, while the left parties sometimes appeal to Muslim minorities (Dancygier, 2017), they do not differentiate Muslims as moderate/secular vs strict/religious. Therefore, we do not expect that being "strict" or "moderate" Muslim will predict their voting behaviors in Belgium (No main effect of Muslim identity content in Belgium).

On the contrary, religion is a salient and dominant cleavage among voters in Turkey (Kalaycioglu, 1994; Carkoglu, 2007; Gidengil \& Karakoc, 2014). Moreover, the parties in Turkey position themselves along this religious cleavage, where the main conservative/rightwing party in power (AKP) targets religious voters, for whom parties' pro-Islamist appeals 
are the key reason to support the party (Gidengil \& Karakoc, 2014). We thus expect that "strict" Muslims would be more likely to vote for right-wing parties in Turkey (Main effect of Muslim identity content in Turkey).

\section{Intersectionality: Religious Identity Content and Left-right ideology}

Beyond their unique effects, this study relates the intersection of Muslim identity content with left-right ideology to voting behavior. We apply the notion of intersectionality to the intersection of religious identity with left-right ideology (Deaux, 2001). Most research on intersectionality refers to intersections of race and gender. We know of one study (Baysu \& Phalet, 2017) that looked at the intersectionality of Muslim identification and political identities (such as secular, liberal, conservative) among the Gezi Park protest participants in Turkey. Accordingly, political identities qualified the meaning and consequences of Muslim identification for democratic attitudes: while for liberals and secularists, Muslim identification was unrelated to democratic attitudes, for conservatives, it was related to weaker democratic attitudes. Similarly, Muslim identity may carry different meanings and consequences across left-right ideological position. From the perspective of the cleavage theory, this refers to cross-cutting cleavages (e.g., Powell, 1976). One's religiosity might motivate them to vote in one way, for instance, for more conservative parties, while their ideological position might motivate them to vote otherwise. This question is rather exploratory, however.

\section{Method}

\section{Participants}

The data was part of a large-scale election survey in Belgium, with representative samples of majority and Turkish and Moroccan minority adults, who were entitled to vote in the 2014 elections in two Belgian cities (Liege and Antwerp). A simple random sample of 500 to 700 persons for each group was drawn based on the citizen register data provided by the two city 
administrations. A Computer Assisted Personal Interview (CAPI) was used with a standardized questionnaire. We focused on Turkish minorities $(\mathrm{N}=447,73 \%$ Antwerp, 27\% Liege). The response rate was $38 \%$ for Turkish Belgians across both cities. To ensure representativeness, the weights were calculated based on the comparison of the completed sample with the known distribution of gender and age in the population from which the sample was taken (see data-codebook for details, Swyngedouw et al., 2016). In addition to Belgian citizenship, 75\% also had Turkish citizenship, hence were dual citizens. They were 18-years or older $(M=36.28, S D=11.93$, range: $18-73$ years, $49 \%$ woman $)$, and half were second-generation (i.e., born in Belgium with one or both parents born in Turkey). While $43 \%$ had middle-school degree or less, $41 \%$ had high-school and $16 \%$ had university degree. Since we focused on the Muslim identity, we included only those who self-identified as Muslims $(n=379,85 \%)$. Sample descriptives for the self-identified Muslims were similar: 79\% dual citizen, 77\% Antwerp, 50\% woman, M_age $=36.29$, SD_age=11.96, 51\% secondgeneration, $45 \%$ middle-school, $41 \%$ high-school, $14 \%$ university.

\section{Measures}

Table 1 shows means, SDs and correlations of the study variables.

Voting Behavior in Turkey indicated which candidate participants voted for or-if they did not vote-would have voted for in the presidential elections of Turkey in 2014 (32\% and 53\% responses, respectively). The answers for both questions were combined and dummy-coded with 1 = right-wing for Recep Tayyip Erdogan (the candidate for AKP, the conservative/right-wing incumbent party), and $0=$ left-wing for Ekmeleddin İhsanoğlu or Selahattin Demirtaş (the candidates for CHP_center-left— and HDP—left-wing - parties, respectively).

Voting Behaviors in Belgium referred to voting for the chamber, the regional government and the European parliament in 2014 elections. The answers were dummy-coded 
for 1 = right-wing $(\mathrm{N}-\mathrm{VA}$-Flemish nationalists, Open VLD-liberal party, Lijst Dedecker-populist party, MR-liberal party, FDF-Francophone nationalist party, Parti Populaire-extreme right-wing party, Vlaams Belang-extreme right-wing party), and $0=$ left-wing (Groen-Green party, PS-social democratic party, Ecolo-green party, Sp.a-social democratic party, PVDA+—communist party, PTB-GO! —communist party). Two center parties were coded as right-wing as they were small (CD\&V-Christiandemocratic party, cdH-Francophobe Christian democratic party).

Authoritarian Attitudes were measured with five items on a scale from 1 (Strongly disagree) to 5 (Strongly agree): e.g., "Laws should become stricter because too much freedom is not good for people", $\alpha=0.70$ (adapted from Middendorp, 1991).

Political deprivation was measured with one item on a scale from 1 (never) to 5 (often): "Some people feel disregarded or abandoned by politics. Do you ever feel like this?" (adapted from Craig et al., 1990 by Abts, 2012). As measures of deprivation, we also had relative group deprivation (five items, e.g., "the government does more for Belgians than for people of my descent", $\alpha=0.70$ ), personal discrimination (two items measuring personallyexperienced discrimination during childhood or in the last five years, $\alpha=.72$ ) and group discrimination (six items measuring whether respondents think their group experience discrimination in different situations, $\alpha=.86$ ). These measures were not significantly related to voting behaviors. Thus, we dropped these measures from further analyses but kept them in the Correlation Table.

Political efficacy was measured with one item on a scale from 1 (no influence at all) to 5 (a lot of influence): "Some people feel they cannot exert any influence on politics, others feel they do have a certain influence. To what extent do you feel you have an influence on political matters?” (adapted from Craig et al., 1990 by Abts, 2012).

Left-right ideology ranged from $0=$ very left-wing to $10=$ very right-wing. 
Muslim identity content was derived from the latent class analysis of three religious practices: How often do you attend religious services or gatherings, for example at a mosque $(1=$ never, $2=$ Seldom, $3=$ Only on religious holidays, $4=$ Once or twice per month, $5=$ once a week or more $)$, how often did you fast during the last Ramadan $(1=$ never, $2=$ Now and then, 3 = Most of the times, $4=$ always $)$, how often do you perform the daily prayer $(1=$ never, 2 = Only on religious holidays, $3=$ Once a week, $4=$ Daily, $5=5$ times a day or more). The two classes that emerged from this analysis were used as a dummy-coded predictor variable (see the Results for details).

National and ethnic identifications referred to feelings of connection to Belgium and Turkey on a scale from 1 (not connected at all) to 5 (strongly connected). Neither affected voting behaviors significantly. We also explored the interactions of national identity with ethnic and religious identities, indicating a dual identity, and found no significant interactions. Thus, we dropped ethnic and national identity from further analyses but kept them in the correlation table.

Control variables were participants' age, gender (woman versus man as the reference), education (two dummy-coded variables, university and high-school versus middle school or less as the reference), migration generation (second versus first-generation as the reference) and the city they live (Liege versus Antwerp as the reference).

\section{Results}

\section{Latent class analyses of Muslim identity content}

We conducted latent class analyses (LCA) of religious practices separately for men and women using Mplus 7 (Muthén \& Muthén, 1998-2012). Examining the two-to-four class models, we selected two-class models for both women and men by comparing the interpretability and statistical soundness of different models (Table 2). Among women, comparing the two-to-three class model, the two-class model gave better or similar fit 
statistics (lower Bayesian Information Criterion [BIC], similar Akaike Information Criterion [AIC]), and the three-class model did not significantly improve the fit using the Rubin test (LMR). Although three-class model had slightly higher entropy, the additional class was very small. Thus, a two-class model was the best fit for our data. Among men, although the twoand three-class models had similar fit statistics, the additional cluster was very small (with overall low religious practice). We thus chose the two-class model for consistency across genders $^{2}$.

Figure 1 shows the summed probability of the two highest frequency for each religious activity for the two classes among women and men (e.g., for the prayer, combined probability of $4=$ daily and $5=$ five times $a$ day). We labelled the classes as "strict" versus "moderate" Muslims who had high versus moderate probabilities for doing any religious activity. Women and men differed in mosque attendance. "Strict" Muslim women were less likely to attend mosque compared to "strict" Muslim men. This difference is about the nature of the religious activity itself rather than Muslim identity content. Put differently, just because "strict" Muslim women do not attend mosques to the same extent as men, that does not mean they are less "strict" Muslims. We will thus use the pooled measure of strict versus moderate Muslims across genders in the following analyses to increase power.

\section{Hierarchical Regression Analyses}

We ran separate logistic regression analyses using SPSS 24 with four voting behaviors as dependent variables, i.e., voting for right-wing versus left-wing parties in Turkey, in the chamber, regional and EU elections of Belgium. We analyzed the predictors in a stepwise fashion: control only model (age, city, gender, education, gender, generation), typical predictors of voting (authoritarianism, deprivation, efficacy), main predictors of

\footnotetext{
${ }^{2}$ We also conducted LCAs without weights, which yielded similar results. Moreover, the bootstrap likelihood ratio test (BLRT) showed that three-class models did not show significant improvement over the two-class models for both genders, confirming our choice for a two-class model.
} 
interest (Moderate versus Strict Muslims and left-right ideology), and the two-way interaction between Muslim identity and ideology (Tables 3a-3d). We centered continuous variables so that probabilities are calculated at the mean levels of the continuous variables, and in the reference-category of the dummy-coded variables.

Authoritarianism, political deprivation, political efficacy (see second step in Tables 3a-3d). For voting in Turkey, authoritarianism, high political deprivation and low efficacy were associated with increased chances of right-wing voting. These effects were robust when adding the other predictors. For voting in Belgium, authoritarianism had no effects, while political deprivation and lack of efficacy were associated with left-wing voting. Deprivation effects disappeared after adding the other predictors. The three predictors explained 5-8\% variance in voting behaviors: the most in Turkey and the Belgian EU elections and the least in the regional elections of Belgium.

Moderate versus Strict Muslims and left-right ideology. Looking at the third step of regression analyses, moderate Muslims were 2.7 (=1/0.37) times less likely to vote for right-wing parties in Turkey compared to strict Muslims, whereas ideology had no significant effects (explaining 6\% variance). For Belgium, across three types of elections, those leaning right-wing were 1.5 times more likely to vote for right-wing parties, whereas Muslim identity content had no significant effects (explaining 13-14\% variance).

We found significant interactions between Muslim identity content and left-right ideology across all four voting behaviors explaining an additional 2\% variance (only marginal for Belgian regional voting). Looking at the estimated probabilities (Figure 2), the likelihood for voting for right-wing parties was very high in Turkey and low in Belgium. Compared to strict Muslims, moderate Muslims were more likely to vote based on their leftright ideology, that is, left-leaning moderate Muslims were more likely to vote for left-wing 
parties. Conversely, strict Muslims, regardless of their ideology, were more likely to vote for right-wing parties in Turkey and left-wing parties in Belgium.

Additional Analyses in the Supplementary Online Material (SOM). We ran several additional analyses, and their details can be found in the SOM. First, we confirmed the robustness of the models regarding logistic regression assumptions about the number of predictors, sample and cell size. Second, to further check the robustness of the models, we ran multivariate logistic regression analyses (i.e., four voting behaviors in one model) using Mplus 7. All the results replicated. These models also confirmed the non-significant effects of personal and group discrimination. Third, we explored the effects of participants' positions on socio-cultural issues (e.g., gay couples' right to adopt children) and economic issues (e.g., government subsidized healthcare) in addition to their left-right self-placement. We found that Turkish-Muslim Belgians' opinions in these issues did not overlap with their left-right self-placement (marginal or non-significant correlations). However, their position on sociocultural issues was significantly related to their Muslim identity content so that moderate Muslims were more accepting of these issues. Moreover, their openness about socio-cultural issues and support for government-subsidized healthcare predicted their voting for left-wing parties in Turkey and in Belgium respectively. All the other effects (including that of leftright self-placement) replicated. Finally, although our focus was on Muslim identity and thus we limited the sample to those who self-identified as Muslim, SOM shows additional analyses on voting behaviors of non-Muslim Turkish-Belgians.

\section{Discussion}

Against the background of a hostile climate against Muslim minorities in Western countries, and suspicions around their politicization, it was timely to investigate their voting behaviors - whether and when they would vote for right-wing versus left-wing parties. Focusing on Turkish-Muslim minorities in a Western-European country, we asked whether 
their religious identity as Muslim or left-right ideological position would predict their voting, besides political deprivation, efficacy and authoritarianism. Theoretically, we combined the social-identity perspective with the social cleavage theory and separate lines of research on majority voting behavior and political integration of immigrant-minorities. Additionally, we looked at minority voting behaviors both in their country of residence and origin, allowing us to see the role of group position and national context in explaining the processes behind their voting preferences.

Our research contributes to the social-political psychology literature on majority voting behavior. We find that for Turkish-Muslim minorities in Belgium, authoritarianism, high political deprivation and inefficacy predicted right-wing voting in Turkey, where they are a part of the majority. This replicates the research on majority members in Europe showing how authoritarianism (Meloen et al., 1996; Aichholzer \& Zandonella, 2016; Cornelis \& Van Hiel, 2015), deprivation (Marchlewska et al., 2018; Urbanska \& Guimond, 2018) and lack of efficacy (Swyngedouw \& Depickere, 2007) predict right-wing voting. Going beyond this research, we also show that strong feelings of political deprivation and inefficacy are not inherently related to right-wing voting, but rather these associations work depending on the group position. Accordingly, we found that political deprivation and inefficacy predicted left-wing voting in Belgium. As a disadvantaged minority, those Muslim citizens, who feel abandoned by and having no influence on Belgian politics, tend to vote for left-wing parties, as the left is more likely to give them a voice (Dancygier, 2017).

It is interesting to note that while political deprivation, or the feelings of disregard and abandonment by politics, predicted Muslim minorities' voting for the right in Turkey and for the left in Belgium, experiences of relative group deprivation or discrimination had no significant effects on their voting behavior. Previous research on relative group deprivation and right-wing voting among majorities typically frame ingroup disadvantage relative to an 
outgroup that is targeted by right-wing parties. For instance, when ingroup disadvantage was framed in comparison to immigrants, it predicted voting for Trump in the US (Marchlewska et al., 2018), and extreme right-wing parties in France (Urbanska \& Guimond, 2018). When ingroup disadvantage was framed with reference to Europe, British participants were more likely to support Brexit (Marchlewska et al., 2018). Thus we can speculate that this measure would be less applicable to predict minorities' voting behavior, as their ingroup disadvantage is usually framed vis a vis the majority society and the political parties are unlikely to view and blame the majority as an outgroup. As for discrimination, previous research shows that experiences of discrimination may have both politicizing and depoliticizing effects on Muslim minorities' political participation (protest and support for Islam, respectively) in Europe (Fleischmann et al. 2011), but it is less clear whether and how it would affect their voting behavior. Thus more research is needed on the role of different measures of deprivation for explaining voting behavior among minorities.

Our findings also advance the research on political integration of immigrantminorities. First, there is growing comparative evidence on political participation of Muslim immigrant-background minorities across Europe, investigating whether their Muslim identity is a bridge or barrier for their political participation in the country of residence (Fleischmann et al. 2011; Just et al., 2014; Kinnvall, \& Nesbitt-Larking, 2011; Kranendonk e al., 2018). However, the findings portray a complex picture, documenting positive, zero and even negative associations between Muslim identity and political participation. One reason behind this inconsistency could be the failure of this research to consider religious identity content. Accordingly, we aimed to de-amalgamate religious identity by looking at distinct ways of being Muslim bottom-up by analyzing various religious practices as a behavioral component of their identity content (Ashmore et al., 2004). We distinguished "strict" Muslims with high levels of religious practice from "moderate" Muslims with low-to-moderate levels of 
practice. We also explored whether women and men engaged in being Muslim differently, given the gender-specific nature of certain religious practices. And indeed, we found that for Muslim women compared to men, being "strict" did not necessarily mean going to mosque as often.

Secondly, by bridging the social identity perspective (Tajfel \& Turner, 1986; Van Zomeren et al., 2008) and the social cleavage theory (Lipset \& Rokkan, 1967), we showed unique effects of religious identity content and left-right ideology in Turkey and Belgium respectively. Only being "strict" vs "moderate" Muslim predicted their voting in Turkey such that "strict" Muslims were more likely to vote for the right-wing/conservative parties (i.e., the AKP) in Turkey. Contrastingly, in Belgium only ideology predicted their voting such that right-leaning were more likely to vote for right-wing parties. This is in line with the social cleavage theory: while left-right ideology is the most salient cleavage in Europe, secular vs. religious distinction is the most salient cleavage in Turkey. The salience of the cleavage in the national context makes the difference.

For voting in Turkey, the significance of religious identity content confirms that for religious voters, the AKP's pro-Islamist stance is the reason to support the party, regardless if its performance (Gidengil \& Karakoc, 2014). Finding no significant effect of left-right ideology, however, is in contrast to the election studies in Turkey that report unique contributions of both ideology and religiosity (Carkoglu, 2008; Toros, 2013). This could be due to Turkish-Muslim minorities' lack of knowledge about the ideological underpinnings of parties in Turkey. Lafleur and Sanchez-Dominquez (2014) made a similar argument in the case of Bolivian emigrants' voting in the origin country.

For voting in Belgium, the significance of ideology is in line with extensive research on the importance of left-right ideology for majority members' voting in Europe (Van der Brug et al., 2000; Winter et al., 2006). However, given the hostile attitudes of right-wing 
parties against Muslim minorities (Schmuck \& Matthes, 2018), overall probabilities of Muslim voting for the right in Belgium were low. Still, a small percentage of Muslim minorities across several countries such as the UK, US and France vote for right-wing parties (Clemens, 2017; Khemilat, 2017; Pew Research Center, 2017c), and our research shows that ideology might play a role. Finding that the Muslim identity content did not contribute to the explanation of voting in Belgium was expected, as this is not a relevant cleavage in Europe.

Thirdly, from the perspectives of both intersectional social identities (Deaux, 2001) and cross-cutting cleavages (Powell, 1976), we explored the intersectionality of Muslim identity content with ideology. Across four elections in Turkey and Belgium, "moderate" Muslims were more likely to vote according to their ideology_right-leaning voting for the right, whereas "strict" Muslims were more likely to vote according to their interests as a disadvantaged minority in Belgium — thus voting for the left—or as a devout Muslim in Turkey - thus voting for the right. This finding suggests that the strategic and divergent voting behaviors of Muslim minorities in Europe vs. Turkey could be more common among “strict" Muslims. From the perspective of social identity performance (Klein et al., 2007), strict Muslims in Europe are more likely to consolidate their religious identity (as in showing stronger religious practices) in response to the increasing public disapproval of and even bans against certain religious practices (such as wearing headscarf). But also, they are more likely to mobilize politically around this identity. Voting for left-wing parties could be one way of mobilization, i.e., coordinated action toward specific goals, for their civic engagement in mainstream politics. Overall, the intersectionality suggests that a common Muslim identity does not have the same political implications for voting in Belgium and Turkey and that this also depends on their different political stances such as their ideology (Baysu \& Phalet, 2017). 
We also had theoretical challenges. First, it would have been ideal to have a measure of voting behaviors at the parliamentary elections instead of presidential elections in Turkey to have the full spectrum of political parties, since the presidential elections usually have limited number of candidates. However, in the case of Turkey, we still covered most of the parties in terms of their representativity in the parliament and their electorate. To illustrate, in the 2015 general election in November, only four parties entered the parliament due to $10 \%$ threshold rule in Turkey: AKP (right-wing), CHP (center-left), MHP (right-wing) and HDP (left-wing). Only MHP was missing in the presidential elections, because they supported the AKP candidate. In terms of the electorate, those voting for other (than these four) parties were $2.5 \%$. Among the voters registered abroad, the percentage of those who voted for other parties was even less, only $1 \%$. Thus, $99 \%$ of the electorate abroad voted for these four parties, which were represented by the three candidates in the presidential elections.

Second, we grouped several parties into left-wing versus right-wing dichotomy due to small sample sizes. This brings up the question whether the meaning of left-right ideological position of parties is the same across contexts. While some authors have explained that the LR positioning of parties varies over time and across culture (Knutsen, 1998), others have assigned a stable and intrinsic meaning to this political category linking it with attitudes towards equality (Bobbio, 1996). Even if it varies over time and across culture, it still represents the dominant ideological position (Middendorp, 1991). We can also compare both countries’ left-right party positions. For Turkey, Özbudun (2006) presents a similar positioning of the parties for left vs right dichotomy from 1950 to 2002. Despite its proIslamist appeals, the ideology of AKP is not fundamentally different compared to Western conservative-Christian democratic parties, or from other center-right parties in Turkey. However, the meaning of the left-right positioning of parties in Turkey relies more on socialcultural issues (particularly the secularist vs conservative cleavage) than on social-economic 
issues (Özbudun, 2006). Similarly, Carkoglu and Hinich (2006) find that the secularist vs conservative cleavage in party positions is parallel to the left-right positioning of the parties, similar to Western traditions. For Belgium and Europe overall, Van der Brug et al (2000) argues and finds that the left-right ideological position is historically and currently one of the most salient cleavages determining party positions as well as voting behavior (Lipset \& Rokkan, 1967; Van der Brug et al., 2000). Thus across contexts, although with slight differences in meaning, left-right ideological positioning of parties is a still relevant comparison criterion.

Third, although one item left-right self-placement measure is valid indicator of people's overall political orientation (Kroh, 2007), it does not tell much about their positions on specific socio-cultural or economic issues. Interestingly, despite being overall conservative in social-cultural issues (Dancygier, 2017), participants in this study positioned themselves at the center in left-right placement. Additional analyses regarding their position on the socio-cultural issues showed that it was more strongly related to their Muslim identity than their left-right self-placement, as such, it predicted their voting in Turkey, rather than in Belgium. On the contrary, their stance on government-subsidized healthcare as part of the socio-economic issues predicted their voting in Belgium. While these additional findings provided a more nuanced picture of the ways ideology might affect voting behaviors, they also confirmed that issue-specific opinions do not necessarily overlap with left-right selfplacement (Winter et al., 2006).

Fourth, we did not measure religious belonging or attachment. While "strict" Muslims would possibly report high religious attachment, "moderate" Muslims could report low or moderate attachment. Finally, our study was limited to one Western-European context. Interestingly, Turkish-Muslim minorities in the US — most of whom are highly-skilled immigrants - tend to vote for left-wing parties in Turkey (and in the US). We would still 
expect their Muslim identity content (secular/moderate vs. strict) to contribute to the explanation of their voting behavior in Turkey (and not in the US). Future research should investigate whether and how their ideology across liberal-conservative dimension would qualify their Muslim identity content and in turn affect their voting behaviors.

We also had other limitations. First was our use of single indicators. Large representative surveys generally present a challenge or trade-off between having externally valid representative samples vs. concerns about internal validity of single-item measures. However, we ran several additional analyses that confirmed the robustness of our models (as explained in SOM). Second, small cell sizes in the outcome variable (e.g., percentage of voting for the right in Belgium) together with high numbers of predictors could cause issues in logistic regression, however, we ran robustness checks to ensure that the bias would be minimum. Finally, given the correlational nature of the study, causal inferences are limited. To conclude, voting is key to political integration of immigrant-background minorities, but what determines their voting preferences remains largely unclear. Dualcitizen minorities can vote differently in their countries of residence and origin. For instance, Turkish-minorities vote for right-wing parties in Turkey and left-wing parties in Europe. Our findings highlight how typical predictors of right-wing voting such as political efficacy and deprivation might have opposite effects for party preferences, depending on the voters' majority vs minority positions in society. Moreover, bridging the social-identity theory with social cleavage theory, we show the unique role of religious identity content and left-right ideology for voting in the country of origin and residence, respectively. Finally, our findings highlight how the meaning of Muslim identity and its relationship to political behavior also depends on left-right ideology. Thus, Muslim identity is not a uniform identity; it has different meanings and consequences for political behaviors. 


\section{References}

Abrams, D., \& Grant, P. R. (2012). Testing the social identity relative deprivation (SIRD) model of social change: The political rise of Scottish nationalism. British Journal of Social Psychology, 51(4), 674-689.

Abts, K. (2012), Maatschappelijk onbehagen en etnopopulisme. Burgers, ressentiment, vreemdelingen, politiek en extreem rechts, PhD-Thesis, KU Leuven, Faculty of Social Sciences.

Aichholzer, J., \& Zandonella, M. (2016). Psychological bases of support for radical right parties. Personality and Individual Differences, 96, 185-190.

Altemeyer, B. (1981). Right-wing authoritarianism. Winnipeg: University of Manitoba Press.

Ashmore, R. D., Deaux, K., \& McLaughlin-Volpe, T. (2004). An organizing framework for collective identity: articulation and significance of multidimensionality. Psychological Bulletin, 130(1), 80-114.

Bartolini, S., \& Mair, P. (1990). Identity, Competition, and Electoral. New York: Cambridge University Press.

Baubock, R. (2005). Expansive Citizenship: Voting beyond Territory and Membership, Political Science and Politics, 38(4), 683-687

Baysu, G., \& Phalet, K. (2017). Beyond Muslim identity: Opinion-based groups in the Gezi Park protest. Group Processes \& Intergroup Relations, 20(3), 350-366.

Bobbio, N. (1996). Left and Right: The Significance of a Political Distinction. University of Chicago Press

Brooks, C. (2006). Voters, satisficing, and policymaking: recent directions in the study of electoral politics. Annual Review of Sociology, 32, 191-211.

Craig, S., Niemi, R. \& Silver, G. (1990). Political efficacy and trust: A report on the NES pilot study items. Political Behavior, 12(3), 289-314. 
Çarkoğlu, A. (2007) The Nature of Left-Right Ideological Self-placement in the Turkish Context, Turkish Studies, 8(2), 253-271, DOI: 10.1080/14683840701312245

Çarkoğlu, A. (2008) Ideology or Economic Pragmatism?: Profiling Turkish Voters in 2007, Turkish Studies, 9:2, 317-344, DOI: 10.1080/14683840802012074

Çarkoğlu, A., \& Hinich, M. J. (2006). A spatial analysis of Turkish party preferences. Electoral Studies, 25(2), 369-392.

Clemens, B. (2017). Religious Affiliation and Party Choice at the 2017 General Election. http://www.brin.ac.uk/religious-affiliation-and-party-choice-at-the-2017-generalelection/

Collyer, M. (2014). A geography of extra-territorial citizenship: Explanations of external voting. Migration Studies, 2(1), 55-72.

Cornelis, I., \& Van Hiel, A. (2015). Extreme-right voting in Western-Europe: the role of social-cultural and antiegalitarian attitudes. Political Psychology, 36(6), 749-760.

Dancygier, R.M. (2017). Dilemmas of Inclusion: Muslims in European Politics. Princeton University press.

Deaux, K. (2001). Social identity. In J. Worrell (Ed.), Encyclopedia of women and gender (Vol. 2, pp. 1059- 1067). San Diego, CA: Academic Press.

Dickson, E. S., \& Scheve, K. (2006). Social identity, political speech, and electoral competition. Journal of Theoretical Politics, 18(1), 5-39.

Fleischmann, F., \& Phalet, K. (2012). Integration and religiosity among the Turkish second generation in Europe: A comparative analysis across four capital cities. Ethnic and Racial Studies, 35(2), 320-341.

Fleischmann, F., Phalet, K., \& Klein, O. (2011). Religious identification and politicization in the face of discrimination: Support for political Islam and political action among the 
Turkish and Moroccan second generation in Europe. British Journal of Social Psychology, 50(4), 628-648.

Fleischmann, F., Phalet, K., \& Swyngedouw, M. (2013). Dual identity under threat: When and how do Turkish and Moroccan minorities engage in politics?. Zeitschrift für Psychologie, 221(4), 214.

Foner, N., \& Alba, R. (2008). Immigrant religion in the US and Western-Europe: Bridge or barrier to inclusion?. International migration review, 42(2), 360-392.

Fox, C. L., \& Schofield, J. W. (1989). Issue salience, perceived efficacy and perceived risk: A study of the origins of anti-nuclear war activity. Journal of Applied Social Psychology, $19,805-827$.

Gidengil, E., \& Karakoç, E. (2014). Which matters more in the electoral success of Islamist (successor) parties-religion or performance? The Turkish case. Party Politics, 22(3), $325-338$.

Haslam, S. A., Reicher, S. D., \& Platow, M. J. (2011). The new psychology of leadership: Identity, influence and power. London \& New York: Psychology Press

Huber, J. D., \& Powell, G. B. (1994). Congruence between citizens and policymakers in two visions of liberal democracy. World Politics, 46(3), 291-326.

Jacoby, W. G. (2010). Policy attitudes, ideology and voting behavior in the 2008 election. Electoral Studies, 29(4), 557-568.

Just, A., Sandovici, M. E., \& Listhaug, O. (2014). Islam, religiosity, and immigrant political action in Western-Europe. Social science research, 43, 127-144.

Kalaycioglu, E, (1994) Elections and party preferences in Turkey: Changes and continuities in the 1990s. Comparative Political Studies, 27(3), 402-424.

Khemilat, F. (2017, April 28). Is there such a thing as a 'Muslim vote' in France? https://theconversation.com/is-there-such-a-thing-as-a-muslim-vote-in-france-76058 
Klandermans, B., Van der Toorn, J., \& Van Stekelenburg, J. (2008). Embeddedness and identity: How immigrants turn grievances into action. American Sociological Review, 73(6), 992-1012.

Klein, O., Spears, R., \& Reicher, S. (2007). Social identity performance: Extending the strategic side of SIDE. Personality and Social Psychology Review, 11(1), 28-45

Knutsen, O. (1998). Expert Judgements of the Left-Right Location of Political Parties: A Comparative Longitudinal Study, West European Politics, 21(2), 63-94

Kranendonk, M., Vermeulen, F., \& van Heelsum, A. (2018). "Unpacking” the Identity-toPolitics Link: The Effects of Social Identification on Voting among Muslim Immigrants in Western-Europe. Political Psychology, 39(1), 43-67.

Kroh, M. (2007). Measuring left-right political orientation: The choice of response format. Public Opinion Quarterly, 71(2), 204-220.

Kteily, N., \& Bruneau, E. (2016). Backlash. The politics and real-world consequences of minority group dehumanization. Personality and Social Psychology Bulletin, 43, 87-104. DOI:10.1177/0146167216675334

Lafleur, J.M. \& Sanchez-Dominguez, M (2015). The political choices of emigrants voting in home country elections: A socio-political analysis of the electoral behavior of Bolivian external voters, Migration Studies, 3(2), 155-181, doi: 10.1093/migration/mnu030

Lipset, S. M., \& Rokkan, S. (Eds.). (1967). Party systems and voter alignments: Crossnational perspectives. New York: Free Press.

Marchlewska, M., Cichocka, A., Panayiotou, O., Castellanos, K., \& Batayneh, J. (2018). Populism as identity politics: Perceived in-group disadvantage, collective narcissism, and support for populism. Social Psychological and Personality Science, 9(2), 151-162.

Mardin, S. (1973). Center Periphery Relations: A Key to Turkish Politics?, Deadalus, 2(1), 169-90. 
Meloen, J. D., Van der Linden, G., \& De Witte, H. (1996). A test of the approaches of Adorno et al., Lederer and Altemeyer of authoritarianism in Belgian Flanders: A research note. Political Psychology, 17, 643-656.

Mencutek, Z. S. (2015). External voting: Mapping motivations of emigrants and concerns of host countries. Insight Turkey, 17(4), 145.

Mencutek, Z, S. \& Yilmaz, S. A. (2016). The Implementation of Voting from Abroad: Evidence from the 2014 Turkish Presidential Election. International Migration, 54(3), 173-186. Doi: 10.1111/imig.12229

Middendorp, C. P. (1991). Ideology in Dutch Politics. The democratic system reconsidered 1970-1985. Assen/Maastricht: Van Gorcum

Mummendey, A., Kessler, T., Klink, A., \& Mielke, R. (1999). Strategies to cope with negative social identity. Journal of Personality and Social Psychology, 76, 229-245. DOI: $10.1037 / 0022-3514.76 .2 .229$

Muthén, L. K., \& Muthén, B. O. (1998-2012). Mplus user’s guide (6th ed.). Los Angeles, CA: Author

Kinnvall, C., \& Nesbitt-Larking, P. (2011). The political psychology of globalization: Muslims in the West. Oxford University Press.

Özbudun, E. (2006). Changes and continuities in the Turkish Party system. Representation, 42(2), 129-137

Pettigrew, T. F. (2016). In pursuit of three theories: Authoritarianism, relative deprivation, and intergroup contact. Annual Review of Psychology, 67, 1-21.

Pew Research Center (2017a). Europe's Growing Muslim Population. Report. http://www.pewforum.org/wp-content/uploads/sites/7/2017/11/FULL-REPORT-FORWEB-POSTING.pdf 
Pew Research Center. (2017b). Assaults against Muslims in U.S. surpass 2001 level. https://www.pewresearch.org/fact-tank/2017/11/15/assaults-against-muslims-in-u-s$\underline{\text { surpass-2001-level/ }}$

Pew Research Center. (2017c). U.S. Muslims Concerned About Their Place in Society, but Continue to Believe in the American Dream. http://www.pewforum.org/2017/07/26/findings-from-pew-research-centers-2017-surveyof-us-muslims/

Phalet, K., Baysu, G., \& Verkuyten, M. (2010). Political mobilization of Dutch Muslims: Religious identity salience, goal framing, and normative constraints. Journal of Social Issues, 66(4), 759-779.

Phalet, K., Fleischmann, F., \& Stoijcic, S. (2012). Ways of being Muslim: Religious identities of second-generation Turks. In Crul, M, Schneider, J., \& Lesie, F. (Eds), The European Second Generation compared (pp. 341 - 374). Amsterdam: Amsterdam University Press

Powell Jr, G. B. (1976). Political cleavage structure, cross-pressure processes, and partisanship. American Journal of Political Science, 1-23.

Schmuck, D., \& Matthes, J. (2018). Voting “against Islamization”? How anti-Islamic rightwing, populist political campaign ads influence explicit and implicit attitudes toward Muslims as well as voting preferences. Political Psychology. doi: 10.1111/pops. 12557

Sears, D. O., \& Funk, C. L. (1999). Evidence of the long-term persistence of adults' political predispositions. The Journal of Politics, 61(1), 1-28.

Simon, B., \& Klandermans, B. (2001). Politicized collective identity: A social-psychological analysis. American Psychologist, 56, 319-331 
Simon, B., \& Ruhs, D. (2008). Identity and politicization among Turkish migrants in Germany: the role of dual identification. Journal of Personality and Social Psychology, 95(6), 1354.

Steffens, N. K., \& Haslam, S. A. (2013). Power through 'us': Leaders' use of we-referencing language predicts election victory. PLoS ONE, 8, e77952.

Swyngedouw, M. (2001). The subjective cognitive and affective map of extreme right voters: using open-ended questions in exit polls. Electoral Studies, 20(2), 217-241.

Swyngedouw M., Depickere A. (2007). Expliquer les succès électoraux de l'extrême droite: la 'formule gagnante' de Kitschelt au banc d'essai des élections flamandes de 1999. Revue française de science politique, 57 (2), 187-208.

Swyngedouw, M., \& Ivaldi, G. (2001). The extreme-right utopia in Belgium and France. West European Politics, 24(3), 1-22

Swyngedouw, M., Meuleman, B., Abts, K., Bousetta, H., and Galle, J. (2016). Belgian Ethnic Minorities Election Study 2014. Codebook: Questions and Frequency tables. Leuven: ISPO-KU Leuven \& CLEO/CEDEM-Université de Liège

Tajfel, H., \& Turner, J. (1986). The social identity theory of intergroup behavior. In S. Worchel \& W. Austin (Eds.), Psychology of intergroup relations (pp. 7-24). Chicago, IL: Nelson-Hall.

Toros, E. (2013). Social indicators and voting: The Turkish case. Social indicators research, 115(3), 1011-1029.

Urbanska, K., and Guimond, S. (2018). Swaying to the extreme: group relative deprivation predicts voting for an extreme right party in the French presidential election. International Review of Social Psychology, 31(1): 26, 1-12, DOI:10.5334/irsp.201 
Van der Brug, W., \& Fennema, M. (2007). What causes people to vote for a radical right party? A review of recent work. International Journal of Public Opinion Research, 19, $474-487$

Van der Brug, W., Fennema, M., \& Tillie, J. (2000). Anti-immigrant parties in Europe: Ideological or protest vote?. European Journal of Political Research, 37(1), 77-102.

Van Zomeren, M., Postmes, T., \& Spears, R. (2008). Toward an integrative social identity model of collective action: A quantitative research synthesis of three socio-psychological perspectives. Psychological Bulletin, 134(4), 504.

Vasilopoulos, P., Marcus, G. E., Valentino, N. A., \& Foucault, M. (2016). Fear, anger, and voting for the far right: Evidence from the November 13, 2015 Paris terror attacks. Political Psychology. doi: 10.1111/pops.12513

Verkuyten, M. (2017). Dual identity and immigrants' protest against discrimination: The moderating role of diversity ideologies. Group Processes \& Intergroup Relations, 20(6), 924-934.

Verkuyten, M., \& Yildiz, A. A. (2006). The endorsement of minority rights: The role of group position, national context, and ideological beliefs. Political Psychology, 27(4), $527-548$.

Wiley, S., Figueroa, J., \& Lauricella, T. (2014). When does dual identity predict protest? The moderating roles of anti-immigrant policies and opinion-based group identity. European Journal of Social Psychology, 44(3), 209-215.

Winter, L., Swyngedouw, M \& Dumont, P. (2006) Party system(s) and electoral behavior in Belgium: From stability to balkanisation, West European Politics, 29:5, 933-956, DOI: $10.1080 / 01402380600968836$ 
Walker, I., \& Pettigrew, T. F. (1984). Relative deprivation theory: An overview and conceptual critique. British Journal of Social Psychology, 23, 301-310. doi:10.1111/j.2044-8309.1984.tb00645. 
Table 1. Descriptive Statistics of the Study Variables

\begin{tabular}{|c|c|c|c|c|c|c|c|c|c|c|c|c|c|c|c|c|c|c|c|c|c|c|}
\hline & & $\mathrm{M}(\mathrm{SD}) / \%$ & 1 & 2 & 3 & 4 & 5 & 6 & 7 & 8 & 9 & 10 & 11 & 12 & 13 & 14 & 15 & 16 & 17 & 18 & 19 & 20 \\
\hline 1 & Vote TR & $74 \%$ & & -.05 & .02 & -.08 & $\begin{array}{l}-.12 \\
*\end{array}$ & .15 & .09 & $\begin{array}{l}-.16 \\
* *\end{array}$ & .0 & $\begin{array}{l}-.13 \\
*\end{array}$ & -.01 & -.02 & -.06 & -.06 & .12 & .03 & .02 & .00 & -.07 & -.07 \\
\hline 2 & Chamber BE & $17 \%$ & & & $\begin{array}{l}.84 \\
* *\end{array}$ & $\begin{array}{l}.84 \\
* *\end{array}$ & .19 & -.09 & .08 & .02 & $\begin{array}{l}.34 \\
* *\end{array}$ & .13 & -.10 & $\begin{array}{l}-.13 \\
*\end{array}$ & .06 & -.06 & -.03 & -.03 & .07 & -.03 & .01 & -.05 \\
\hline 3 & Region BE & $16 \%$ & & & & .81 & .19 & -1 & $\therefore 08$ & .04 & .32 & .06 & -.08 & -.06 & $: 03$ & -.08 & .04 & .04 & .02 & -.06 & -.05 & $\begin{array}{l}-.12 \\
*\end{array}$ \\
\hline 4 & EU BE & $21 \%$ & & & & & .19 & $\begin{array}{l}-.14 \\
*\end{array}$ & .04 & -.03 & .30 & .03 & -.07 & $\begin{array}{l}-.20 \\
* *\end{array}$ & .03 & -.08 & .03 & .01 & .09 & -.04 & .04 & -.03 \\
\hline 5 & Pol efficacy & $1.63(.75)$ & & & & & & -.03 & -.06 & .08 & .01 & -.06 & $\cdot .06$ & -.05 & .01 & .02 & .03 & .13 & .11 & -1.0 & .18 & .09 \\
\hline 6 & Pol depriv & $2.75(1.24)$ & & & & & & & $: 01$ & -.07 & $\begin{array}{l}-.19 \\
* *\end{array}$ & .15 & $\begin{array}{l}-.16 \\
* *\end{array}$ & $\begin{array}{l}-.19 \\
* *\end{array}$ & .06 & .03 & -.05 & .05 & $\begin{array}{l}-.12 \\
*\end{array}$ & .28 & .02 & .08 \\
\hline 7 & Authoritarian & $3.61(.65)$ & & & & & & & & .15 & -.07 & .04 & -.06 & -.02 & .11 & -.08 & .06 & .14 & .13 & .06 & .03 & -.06 \\
\hline 8 & Muslim id & $38 \%$ & & & & & & & & & $\begin{array}{l}-.15 \\
* *\end{array}$ & -.05 & -.02 & .02 & .0 & .04 & ${ }_{*} 11$ & $: 05$ & $\begin{array}{l}-.15 \\
* *\end{array}$ & $\begin{array}{l}-.11 \\
*\end{array}$ & -.06 & $\begin{array}{l}-.17 \\
* *\end{array}$ \\
\hline 9 & Ideology & $4.34(2.40)$ & & & & & & & & & & .13 & -.03 & .09 & $-\therefore .07$ & $-\therefore 04$ & $\begin{array}{l}-.12 \\
*\end{array}$ & $: 07$ & .03 & -.05 & $: 02$ & .07 \\
\hline 10 & Age & $36.29(11.96)$ & & & & & & & & & & & .02 & $-\therefore 02$ & $\begin{array}{l}-.25 \\
* *\end{array}$ & -.08 & $\begin{array}{l}-.64 \\
* *\end{array}$ & $: 02$ & -.07 & .18 & $\begin{array}{l}-.15 \\
* *\end{array}$ & $\begin{array}{l}-.18 \\
* *\end{array}$ \\
\hline 11 & City & $77 \%$ & & & & & & & & & & & & -.02 & $-\therefore .02$ & -.06 & -.07 & -.03 & .02 & $\cdot 01$ & -1.0 & -.08 \\
\hline 12 & Gender & $50 \%$ & & & & & & & & & & & & & $-\therefore .06$ & -.04 & -.02 & .06 & .08 & -.09 & $\begin{array}{l}-.18 \\
* *\end{array}$ & $\begin{array}{l}-.16 \\
* *\end{array}$ \\
\hline 13 & $\begin{array}{l}\text { Education: } \\
\text { High school }\end{array}$ & $41 \%$ & & & & & & & & & & & & & & $\begin{array}{l}-.34 \\
* *\end{array}$ & .18 & $: 02$ & .05 & -.04 & .04 & .11 \\
\hline 14 & $\begin{array}{l}\text { Education: } \\
\text { University }\end{array}$ & $14 \%$ & & & & & & & & & & & & & & & .07 & * 1.0 & .01 & -.05 & .21 & .11 \\
\hline 15 & Generation & $51 \%$ & & & & & & & & & & & & & & & & .03 & .02 & $\begin{array}{l}-.16 \\
* *\end{array}$ & .13 & .13 \\
\hline 16 & National id & $3.99(.93)$ & & & & & & & & & & & & & & & & & .27 & $\begin{array}{l}-.15 \\
* *\end{array}$ & -.03 & .0 .0 \\
\hline
\end{tabular}




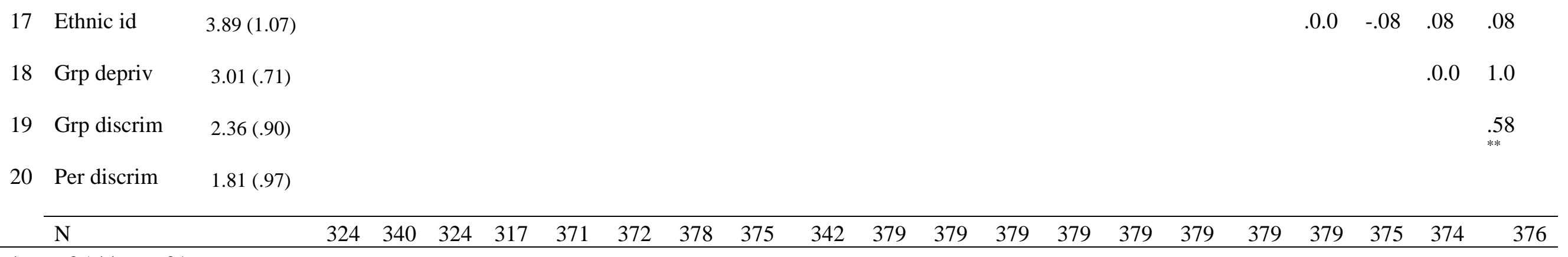

$* \mathrm{p}<.05 * * \mathrm{p}<.01$

Note. Vote TR, chamber BE, Region BE, EU BE indicate percentages of those voting for right-wing (vs left-wing parties) in Turkey and in the chamber, regional and EU elections of Belgium, respectively. For other categorical variables, percentages are presented for the first category: City (Antwerp vs Brussels), Gender (Woman vs Men), Generation ( $2^{\text {nd }}$ vs. $\left.1^{\text {st }}\right)$, Education (High school vs middle school; University vs middle school) 
Table 2. Fit Statistics for Latent Class Analyses of Muslim Identity Content for Women and Men

\begin{tabular}{lllllll}
\hline & Women & \multicolumn{5}{c}{ Men } \\
\hline CLASSES & 2 & 3 & 4 & 2 & 3 & 4 \\
\hline LL & -651.56 & -638.45 & -627.64 & -690.50 & -662.02 & -649.17 \\
\# parameters & 23.00 & 35.00 & 47.00 & 23.00 & 35.00 & 47.00 \\
AIC & 1349.13 & 1346.89 & 1349.28 & 1426.99 & 1394.04 & 1392.34 \\
BIC & 1422.95 & 1459.22 & 1500.12 & 1501.31 & 1507.13 & 1544.21 \\
LMR p & 0.03 & 1.00 & 1.00 & 0.61 & 0.70 & 0.89 \\
ENTROPY & 0.80 & 0.85 & 0.89 & 0.78 & 0.80 & 0.87 \\
CLASS 1 & 71 & 113 & 47 & 69 & 81 & 16 \\
CLASS 2 & 112 & 19 & 16 & 118 & 33 & 61 \\
CLASS 3 & & 51 & 107 & & 73 & 78 \\
CLASS4 & & & 14 & & & 32 \\
\hline
\end{tabular}


Table 3a. Logistic Regression Results: Voting for right-wing (versus left-wing) parties in the presidential elections of Turkey

\begin{tabular}{|c|c|c|c|c|c|c|c|c|}
\hline & $\mathrm{B}(\mathrm{SE})$ & $\begin{array}{l}\text { Exp } \\
\text { (B) }\end{array}$ & $\mathrm{B}(\mathrm{SE})$ & $\begin{array}{l}\text { Exp } \\
\text { (B) }\end{array}$ & $\mathrm{B}(\mathrm{SE})$ & $\begin{array}{l}\text { Exp } \\
\text { (B) }\end{array}$ & $\mathrm{B}(\mathrm{SE})$ & $\begin{array}{l}\text { Exp } \\
\text { (B) }\end{array}$ \\
\hline Constant & $1.72(.36)$ & 5.60 & $1.93(.38)$ & 6.89 & $2.26(.41)$ & 9.60 & $2.28(.42)$ & 9.75 \\
\hline Age & $-0.04(.02)^{*}$ & 0.97 & $-0.05(.02)^{* *}$ & 0.96 & $-0.05(.02)^{* *}$ & 0.96 & $-0.04(.02)^{*}$ & 0.96 \\
\hline $\begin{array}{l}\text { City (Liege vs } \\
\text { Antwerp) }\end{array}$ & $-0.37(.33)$ & 0.69 & $-0.48(.35)$ & 0.62 & $-0.54(.36)$ & 0.59 & $-0.42(.36)$ & 0.66 \\
\hline $\begin{array}{l}\text { Gender (woman } \\
\text { vs man) }\end{array}$ & $-0.44(.28)$ & 0.64 & $-0.23(.30)$ & 0.79 & $-0.22(.31)$ & 0.80 & $-0.18(.32)$ & 0.84 \\
\hline $\begin{array}{l}\text { Higher } \\
\text { secondary (vs } \\
\text { middle school) }\end{array}$ & $-0.78(.33)^{*}$ & 0.46 & $-0.97(.35)^{* *}$ & 0.38 & $-0.96(.36)^{* *}$ & 0.39 & $-1.02(.37)^{* *}$ & 0.36 \\
\hline $\begin{array}{l}\text { University (vs } \\
\text { middle school) }\end{array}$ & $-0.69(.43)$ & 0.50 & $-0.88(.45)^{\mathrm{a}}$ & 0.42 & $-0.87(.46)^{\mathrm{a}}$ & 0.42 & $-0.88(.46)^{\mathrm{a}}$ & 0.42 \\
\hline $\begin{array}{l}\text { Generation ( } 2^{\text {nd }} \\
\left.\text { vs } 1^{\text {st }} \text { gen }\right)\end{array}$ & $0.17(.36)$ & 1.18 & $0.05(.37)$ & 1.06 & $0.21(.38)$ & 1.23 & $0.29(.38)$ & 1.33 \\
\hline Political efficacy & & & $-0.45(.19)^{*}$ & 0.64 & $-0.39(.19)^{*}$ & 0.68 & $-0.38(.19)^{\mathrm{a}}$ & 0.69 \\
\hline $\begin{array}{l}\text { Political } \\
\text { deprivation }\end{array}$ & & & $0.38(.13)^{* *}$ & 1.46 & $0.41(.14)^{* *}$ & 1.50 & $0.39(.14)^{* *}$ & 1.48 \\
\hline Authoritarian & & & $0.37(.22)^{\mathrm{c}}$ & 1.45 & $0.59(.24)^{*}$ & 1.80 & $0.53(.24)^{*}$ & 1.70 \\
\hline $\begin{array}{l}\text { Muslim id (Mod } \\
\text { vs Strict) }\end{array}$ & & & & & $-1.01(.31)^{* *}$ & 0.37 & $-1.0(.32)^{* *}$ & 0.37 \\
\hline $\begin{array}{l}\text { Right-wing } \\
\text { ideology }\end{array}$ & & & & & $0.04(.06)$ & 1.04 & $-0.11(.09)$ & 0.89 \\
\hline $\begin{array}{l}\text { Interaction: } \\
\text { Muslim id x } \\
\text { ideology }\end{array}$ & & & & & & & $0.31(.13)^{*}$ & 1.36 \\
\hline Nagelkerke R2 & 0.07 & & 0.15 & & 0.21 & & 0.23 & \\
\hline
\end{tabular}

Note: Muslim id is short for Muslim identity content (Moderate vs Strict Muslims)

$* p<.05 * * p<.01^{\mathrm{a}} p<.06^{\mathrm{b}} p=<.07^{\mathrm{c}} p<.10$ 
Table 3b. Logistic Regression Results: Voting for right-wing (versus left-wing) parties in the Chamber Elections in Belgium

\begin{tabular}{|c|c|c|c|c|c|c|c|c|}
\hline & $\mathrm{B}(\mathrm{SE})$ & $\begin{array}{l}\text { Exp } \\
\text { (B) }\end{array}$ & $\mathrm{B}(\mathrm{SE})$ & $\begin{array}{l}\text { Exp } \\
\text { (B) }\end{array}$ & $\mathrm{B}(\mathrm{SE})$ & $\begin{array}{l}\text { Exp } \\
\text { (B) }\end{array}$ & $\mathrm{B}(\mathrm{SE})$ & $\begin{array}{l}\text { Exp } \\
\text { (B) }\end{array}$ \\
\hline Constant & $-1.94(.39)$ & 0.14 & $-2.08(.41)$ & 0.13 & $-2.34(.46)$ & 0.10 & $-2.30(.46)$ & 0.10 \\
\hline Age & $0.05(.02)^{* * *}$ & 1.05 & $0.06(.02)^{* * *}$ & 1.06 & $0.05(.02)^{*}$ & 1.05 & $0.06(.02)^{* *}$ & 1.06 \\
\hline $\begin{array}{l}\text { City (Liege } \\
\text { vs Antwerp) }\end{array}$ & $1.00(.35)^{* *}$ & 2.73 & $1.08(.37)^{* *}$ & 2.93 & $0.84(.41)^{*}$ & 2.31 & $1.00(.41)^{*}$ & 2.73 \\
\hline $\begin{array}{l}\text { Gender } \\
\text { (woman vs } \\
\text { man) }\end{array}$ & $-0.35(.32)$ & 0.71 & $-0.52(.34)$ & 0.60 & $-0.65(.37)^{\mathrm{c}}$ & 0.52 & $-0.64(.37)^{\mathrm{c}}$ & 0.53 \\
\hline $\begin{array}{l}\text { Higher } \\
\text { secondary } \\
\text { (vs middle } \\
\text { school) }\end{array}$ & $0.35(.35)$ & 1.42 & $0.41(.37)$ & 1.50 & $0.50(.40)$ & 1.65 & $0.45(.40)$ & 1.57 \\
\hline $\begin{array}{l}\text { University(vs } \\
\text { middle } \\
\text { school) }\end{array}$ & $-0.29(.55)$ & 0.75 & $-0.16(.56)$ & 0.85 & $-0.21(.61)$ & 0.81 & $-0.16(.61)$ & 0.85 \\
\hline $\begin{array}{l}\text { Generation } \\
\left(2^{\text {nd }} \text { vs } 1^{\text {st }}\right. \\
\text { gen })\end{array}$ & $0.21(.42)$ & 1.24 & $0.28(.43)$ & 1.32 & $0.45(.47)$ & 1.57 & $0.56(.48)$ & 1.75 \\
\hline $\begin{array}{l}\text { Political } \\
\text { efficacy }\end{array}$ & & & $0.52(.21)^{*}$ & 1.68 & $0.63(.23)^{* *}$ & 1.87 & $0.65(.23)^{* *}$ & 1.91 \\
\hline $\begin{array}{l}\text { Political } \\
\text { deprivation }\end{array}$ & & & $-0.33(.14)^{*}$ & 0.72 & $-0.17(.16)$ & 0.85 & $-0.17(.16)$ & 0.84 \\
\hline Authoritarian & & & $0.27(.24)$ & 1.31 & $0.45(.27)^{\mathrm{c}}$ & 1.56 & $0.41(.27)$ & 1.51 \\
\hline $\begin{array}{l}\text { Muslim id } \\
\text { (Mod vs } \\
\text { Strict) }\end{array}$ & & & & & $-0.02(.37)$ & 0.98 & $-0.45(.45)$ & 0.64 \\
\hline $\begin{array}{l}\text { Right-wing } \\
\text { ideology }\end{array}$ & & & & & $0.40(.08)^{* * * *}$ & 1.49 & $0.27(.10)^{* *}$ & 1.31 \\
\hline $\begin{array}{l}\text { Interaction: } \\
\text { Muslim id x } \\
\text { ideology }\end{array}$ & & & & & & & $0.40(.19)^{*}$ & 1.49 \\
\hline $\begin{array}{l}\text { Nagelkerke } \\
\text { R2 }\end{array}$ & 0.12 & & 0.18 & & 0.32 & & 0.34 & \\
\hline
\end{tabular}

Note: Muslim id is short for Muslim identity content (Moderate vs Strict Muslims)

$* \mathrm{p}<.05^{* *} p<.01^{\mathrm{a}} p<.06^{\mathrm{b}} p=<.07^{\mathrm{c}} p<.10$ 
Table 3c. Logistic Regression Results: Voting for right-wing (versus left-wing) parties in the Regional Elections in Belgium

\begin{tabular}{|c|c|c|c|c|c|c|c|c|}
\hline & $\mathrm{B}(\mathrm{SE})$ & $\begin{array}{l}\text { Exp } \\
\text { (B) }\end{array}$ & $\mathrm{B}(\mathrm{SE})$ & $\begin{array}{l}\text { Exp } \\
\text { (B) }\end{array}$ & $\mathrm{B}(\mathrm{SE})$ & $\begin{array}{l}\text { Exp } \\
\text { (B) }\end{array}$ & $\mathrm{B}(\mathrm{SE})$ & $\begin{array}{l}\text { Exp } \\
\text { (B) }\end{array}$ \\
\hline Constant & $-2.12(.41)$ & 0.12 & $-2.22(.42)$ & 0.11 & $-2.53(.47)$ & 0.08 & $-2.49(.47)$ & 0.08 \\
\hline Age & $0.04(.02)^{*}$ & 1.05 & $0.05(.02)^{*}$ & 1.05 & $0.04(.02)^{b}$ & 1.04 & $0.05(.02)^{*}$ & 1.05 \\
\hline $\begin{array}{l}\text { City (Liege } \\
\text { vs Antwerp) }\end{array}$ & $0.90(.36)^{*}$ & 2.46 & $0.95(.37)^{*}$ & 2.59 & $0.68(.41)^{\mathrm{c}}$ & 1.98 & $0.82(.41)^{\mathrm{a}}$ & 2.26 \\
\hline $\begin{array}{l}\text { Gender } \\
\text { (woman vs } \\
\text { man) }\end{array}$ & $0.08(.33)$ & 1.08 & $-0.03(.35)$ & 0.98 & $-0.15(.37)$ & 0.86 & $-0.13(.37)$ & 0.88 \\
\hline $\begin{array}{l}\text { Higher } \\
\text { secondary } \\
\text { (vs middle } \\
\text { school) }\end{array}$ & $0.02(.36)$ & 1.02 & $0.06(.37)$ & 1.06 & $0.10(.39)$ & 1.10 & $0.06(.39)$ & 1.06 \\
\hline $\begin{array}{l}\text { University } \\
\text { (vs middle } \\
\text { school) }\end{array}$ & $-0.67(.57)$ & 0.51 & $-0.56(.58)$ & 0.57 & $-0.56(.61)$ & 0.57 & $-0.52(.61)$ & 0.59 \\
\hline $\begin{array}{l}\text { Generation } \\
\left(2^{\text {nd }} \text { vs } 1^{\text {st }}\right. \\
\text { gen })\end{array}$ & $0.60(.44)$ & 1.83 & $0.61(.44)$ & 1.83 & $0.87(.48)^{\mathrm{b}}$ & 2.38 & $0.96(.49)^{\mathrm{a}}$ & 2.62 \\
\hline $\begin{array}{l}\text { Political } \\
\text { efficacy }\end{array}$ & & & $0.48(.21)^{*}$ & 1.62 & $0.55(.23)^{*}$ & 1.74 & $0.57(.24)^{*}$ & 1.77 \\
\hline $\begin{array}{l}\text { Political } \\
\text { deprivation }\end{array}$ & & & $-0.25(.15)^{\mathrm{c}}$ & 0.78 & $-0.08(.17)$ & 0.92 & $-0.10(.17)$ & 0.91 \\
\hline Authoritarian & & & $0.31(.25)$ & 1.36 & $0.42(.27)$ & 1.52 & $0.39(.27)$ & 1.47 \\
\hline $\begin{array}{l}\text { Muslim id } \\
\text { (Mod vs } \\
\text { Strict) }\end{array}$ & & & & & $0.09(.37)$ & 1.09 & $-0.25(.43)$ & 0.78 \\
\hline $\begin{array}{l}\text { Right-wing } \\
\text { ideology }\end{array}$ & & & & & $0.37(.08)^{* * *}$ & 1.45 & $0.25(.10)^{*}$ & 1.29 \\
\hline $\begin{array}{l}\text { Interaction: } \\
\text { Muslim id x } \\
\text { ideology }\end{array}$ & & & & & & & $0.32(.18)^{\mathrm{b}}$ & 1.38 \\
\hline $\begin{array}{l}\text { Nagelkerke } \\
\text { R2 }\end{array}$ & 0.08 & & 0.13 & & 0.26 & & 0.27 & \\
\hline
\end{tabular}

Note: Muslim id is short for Muslim identity content (Moderate vs Strict Muslims)

$* p<.05 * * p<.01^{\mathrm{a}} p<.06^{\mathrm{b}} p=<.07^{\mathrm{c}} p<.10$ 
Table 3d. Logistic Regression Results: Voting for right-wing (versus left-wing) parties in the EU Elections in Belgium

\begin{tabular}{|c|c|c|c|c|c|c|c|c|}
\hline & B (SE) & $\begin{array}{l}\text { Exp } \\
\text { (B) }\end{array}$ & $\mathrm{B}(\mathrm{SE})$ & $\begin{array}{l}\text { Exp } \\
\text { (B) }\end{array}$ & $\mathrm{B}(\mathrm{SE})$ & $\begin{array}{l}\text { Exp } \\
\text { (B) }\end{array}$ & $\mathrm{B}(\mathrm{SE})$ & $\begin{array}{l}\operatorname{Exp} \\
\text { (B) }\end{array}$ \\
\hline Constant & $-1.28(.36)$ & 0.28 & $-1.45(.38)$ & 0.23 & $-1.53(.42)$ & 0.22 & $-1.51(.42)$ & 0.22 \\
\hline Age & $0.03(.02)$ & 1.03 & $0.04(.02)^{\mathrm{a}}$ & 1.04 & $0.03(.02)$ & 1.03 & $0.04(.02)^{\mathrm{a}}$ & 1.04 \\
\hline $\begin{array}{l}\text { City (Liege } \\
\text { vs Antwerp) }\end{array}$ & $0.90(.35)^{*}$ & 2.46 & $1.01(.37)^{* * *}$ & 2.73 & $0.76(.41)^{\mathrm{a}}$ & 2.15 & $0.94(.41)^{*}$ & 2.55 \\
\hline $\begin{array}{l}\text { Gender } \\
\text { (woman vs } \\
\text { man) }\end{array}$ & $-0.75(.32)^{*}$ & 0.47 & $-0.97(.34)^{* *}$ & 0.38 & $-1.21(.37)^{* *}$ & 0.30 & $-1.20(.37)^{* *}$ & 0.30 \\
\hline $\begin{array}{l}\text { Higher } \\
\text { secondary } \\
\text { (vs middle } \\
\text { school) }\end{array}$ & $-0.16(.33)$ & 0.85 & $-0.08(.34)$ & 0.93 & $-0.04(.37)$ & 0.97 & $-0.10(.37)$ & 0.90 \\
\hline $\begin{array}{l}\text { University } \\
\text { (vs middle } \\
\text { school) }\end{array}$ & $-1.32(.61)^{*}$ & 0.27 & $-1.23(.62)^{\mathrm{a}}$ & 0.29 & $-1.35(.68)^{\mathrm{a}}$ & 0.26 & $-1.34(.67)^{\mathrm{a}}$ & 0.26 \\
\hline $\begin{array}{l}\text { Generation } \\
\left(2^{\text {nd }} \text { vs } 1^{\text {st }}\right. \\
\text { gen })\end{array}$ & $0.49(.41)$ & 1.63 & $0.61(.43)$ & 1.84 & $0.97(.47)^{*}$ & 2.64 & $1.08(.48)^{*}$ & 2.93 \\
\hline $\begin{array}{l}\text { Political } \\
\text { efficacy }\end{array}$ & & & $0.59(.20)^{* *}$ & 1.80 & $0.67(.22)^{* *}$ & 1.95 & $0.70(.23)^{* *}$ & 2.01 \\
\hline $\begin{array}{l}\text { Political } \\
\text { deprivation }\end{array}$ & & & $-0.37(.14)^{*}$ & 0.69 & $-0.20(.16)$ & 0.82 & $-0.21(.17)$ & 0.81 \\
\hline Authoritarian & & & $0.08(.24)$ & 1.09 & $0.30(.25)$ & 1.34 & $0.24(.26)$ & 1.27 \\
\hline $\begin{array}{l}\text { Muslim id } \\
\text { (Mod vs } \\
\text { Strict) }\end{array}$ & & & & & $-0.49(.37)$ & 0.61 & $-0.86(.44)^{\mathrm{a}}$ & 0.42 \\
\hline $\begin{array}{l}\text { Right-wing } \\
\text { ideology }\end{array}$ & & & & & $0.37(.08)^{* * * *}$ & 1.44 & $0.25(.09)^{* *}$ & 1.28 \\
\hline $\begin{array}{l}\text { Interaction: } \\
\text { Muslim id x } \\
\text { ideology }\end{array}$ & & & & & & & $0.39(.19)^{*}$ & 1.48 \\
\hline $\begin{array}{l}\text { Nagelkerke } \\
\text { R2 }\end{array}$ & 0.11 & & 0.19 & & 0.32 & & 0.34 & \\
\hline
\end{tabular}

Note: Muslim id is short for Muslim identity content (Moderate vs Strict Muslims)

$p<.05 * * p<.01^{\mathrm{a}} p<.06$ 


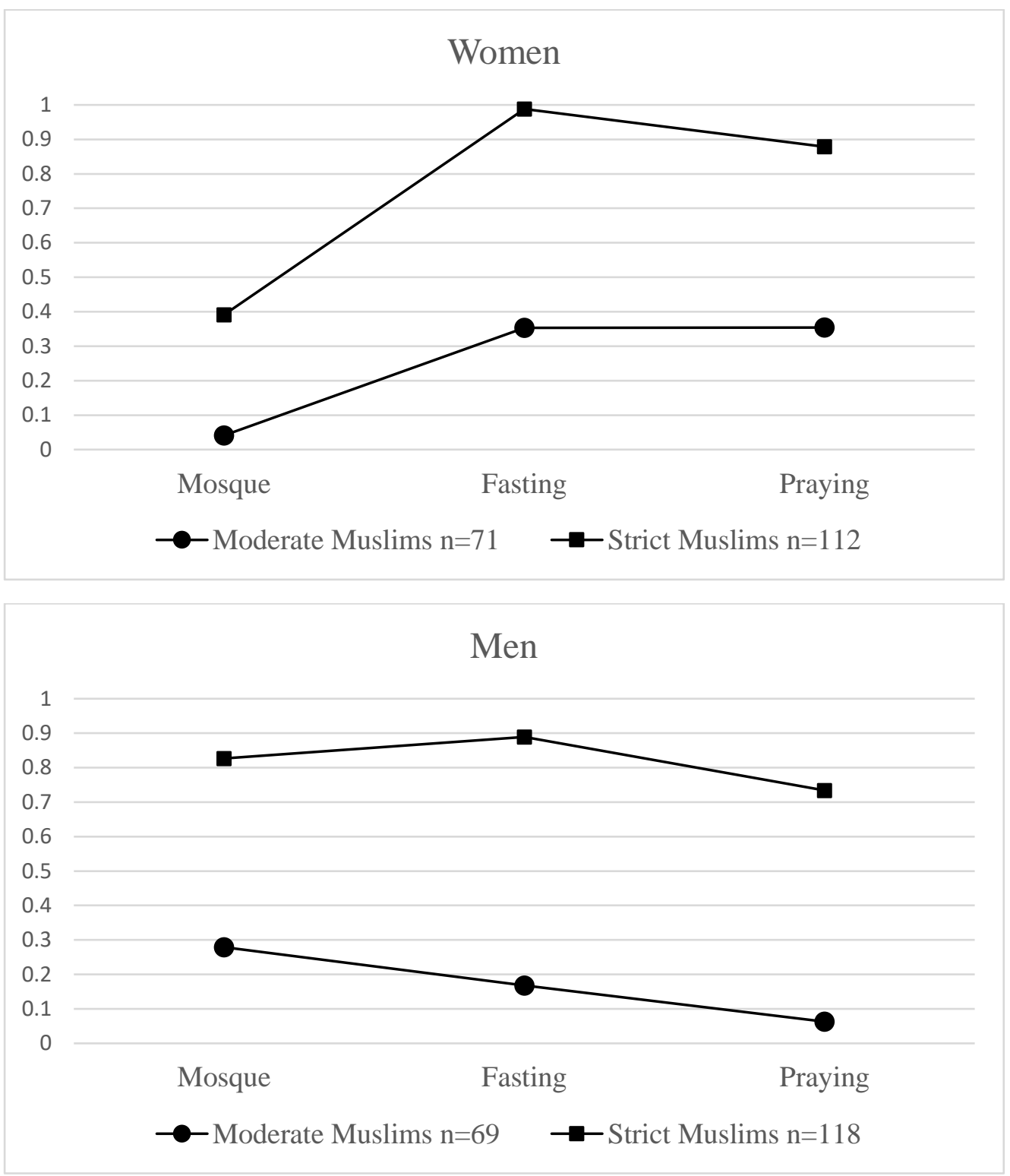

Figure 1. Probability of high religious activity levels by Muslim identity content 


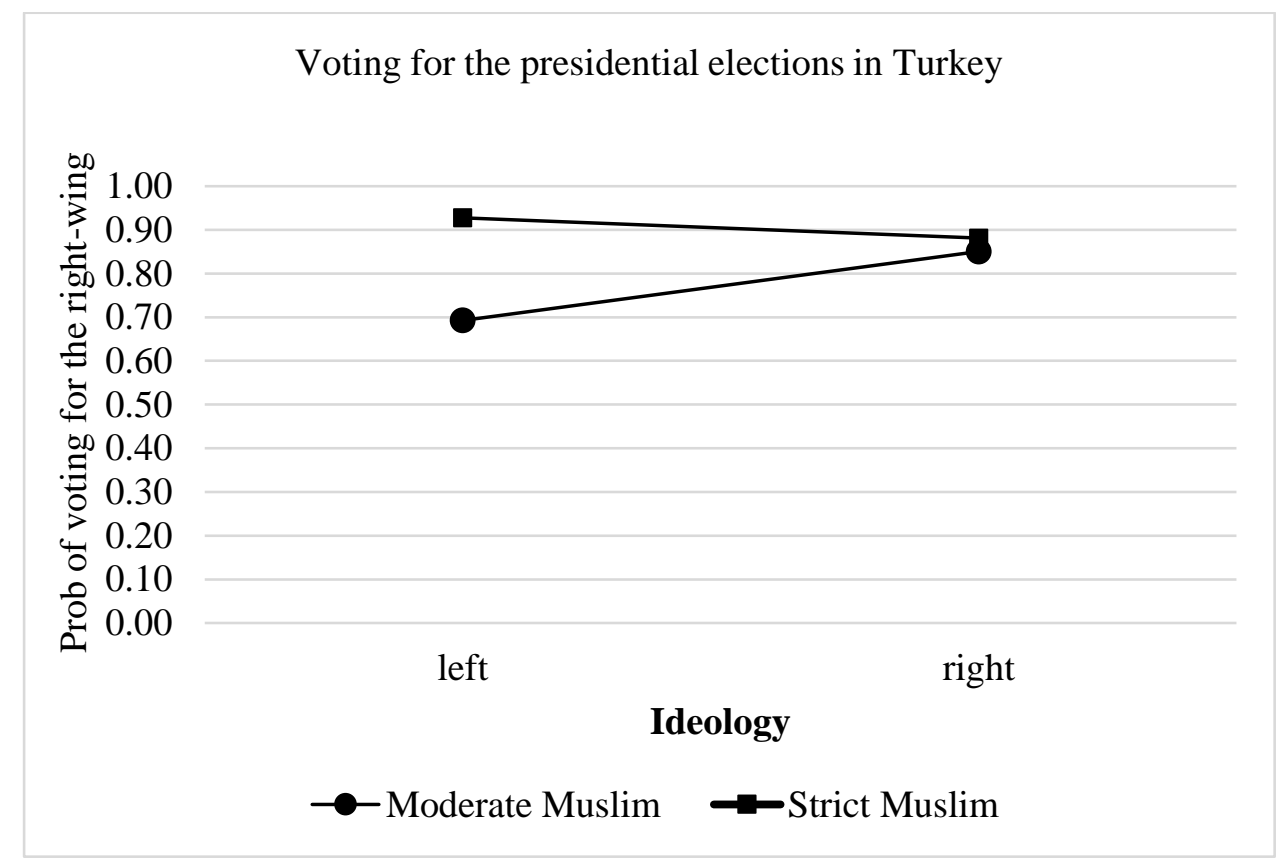

Figure 2a. Probability of voting for right-wing (vs left-wing) parties in Turkey as a function of Muslim identity content and left-right ideology

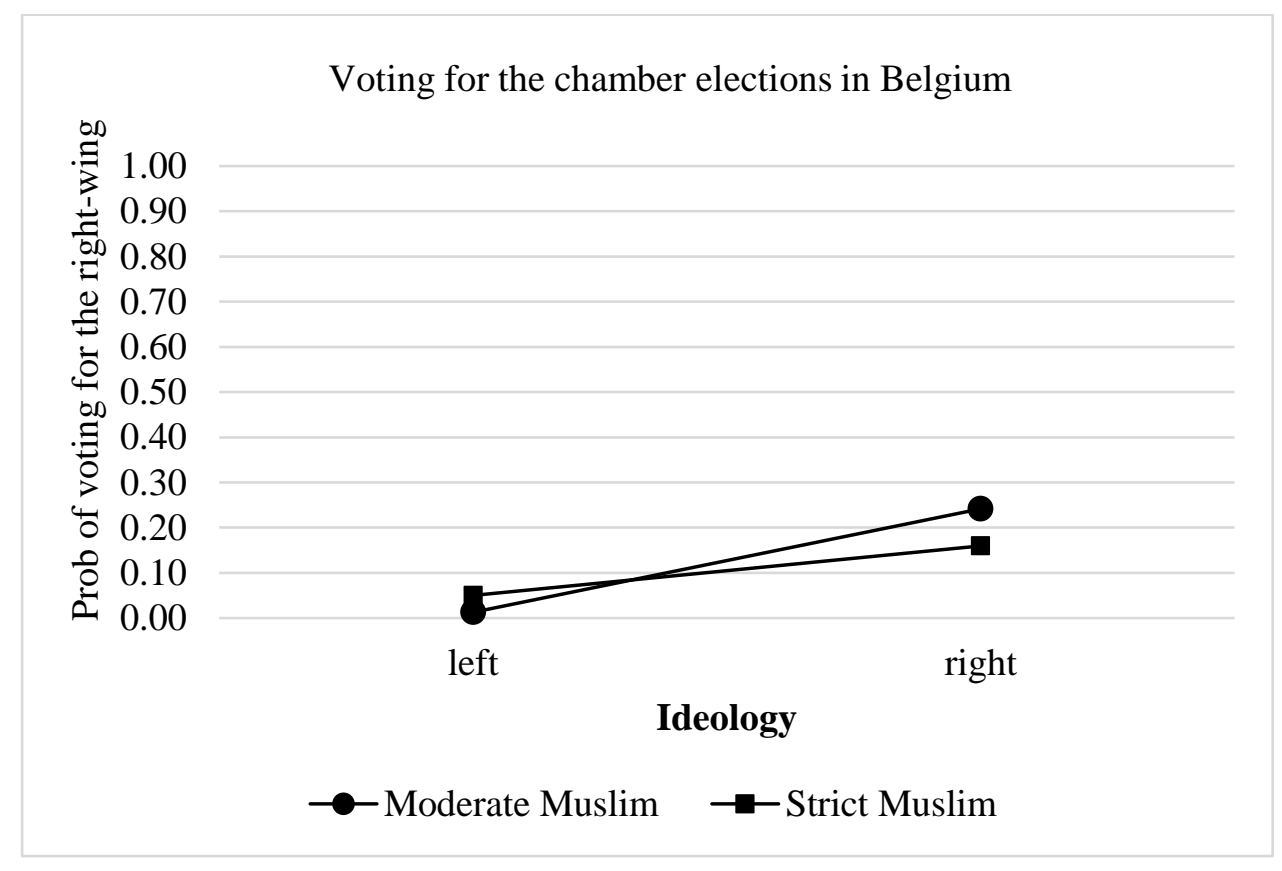

Figure $2 b$. Probability of voting for right-wing (vs left-wing) parties in the chamber elections of Belgium as a function of Muslim identity content and left-right ideology 


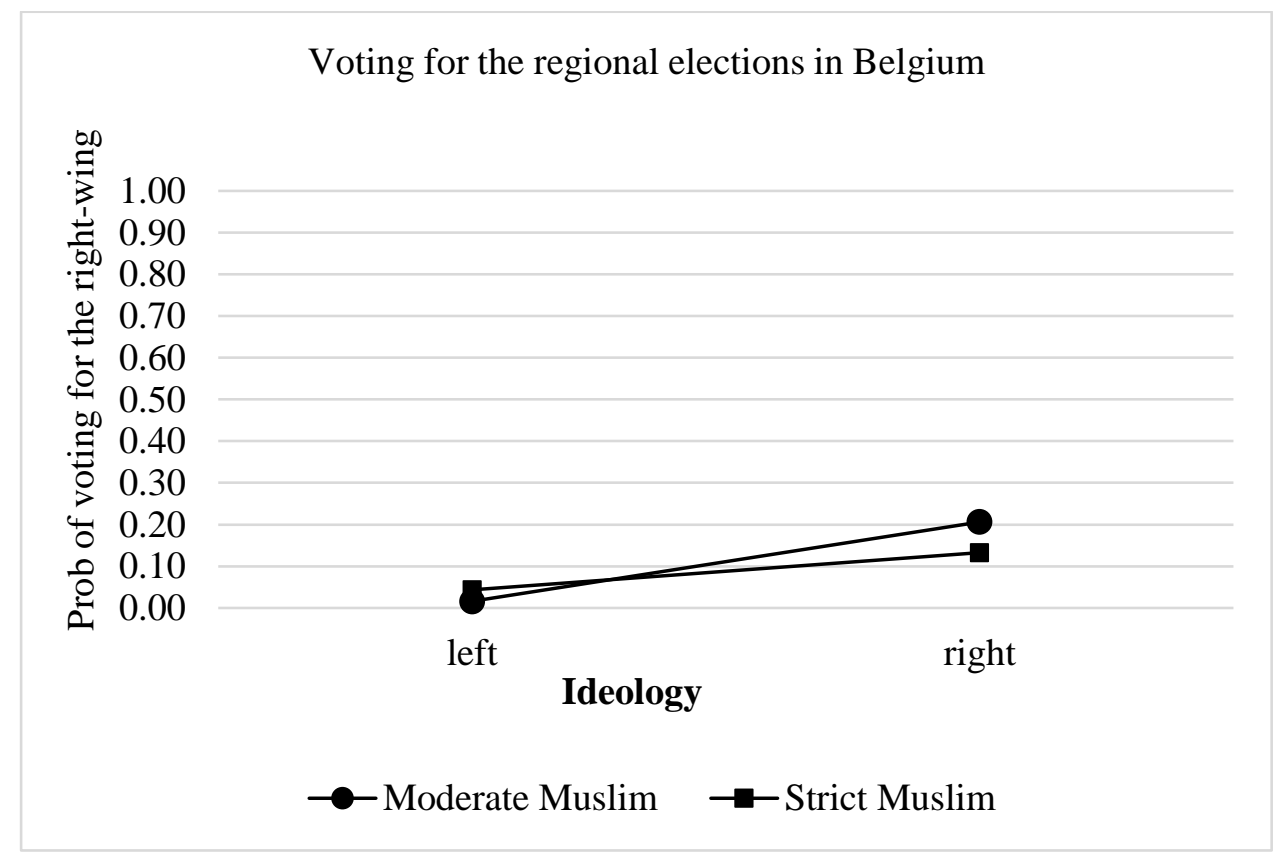

Figure 2c. Probability of voting for right-wing (vs left-wing) parties in the regional elections of Belgium as a function of Muslim identity content and left-right ideology

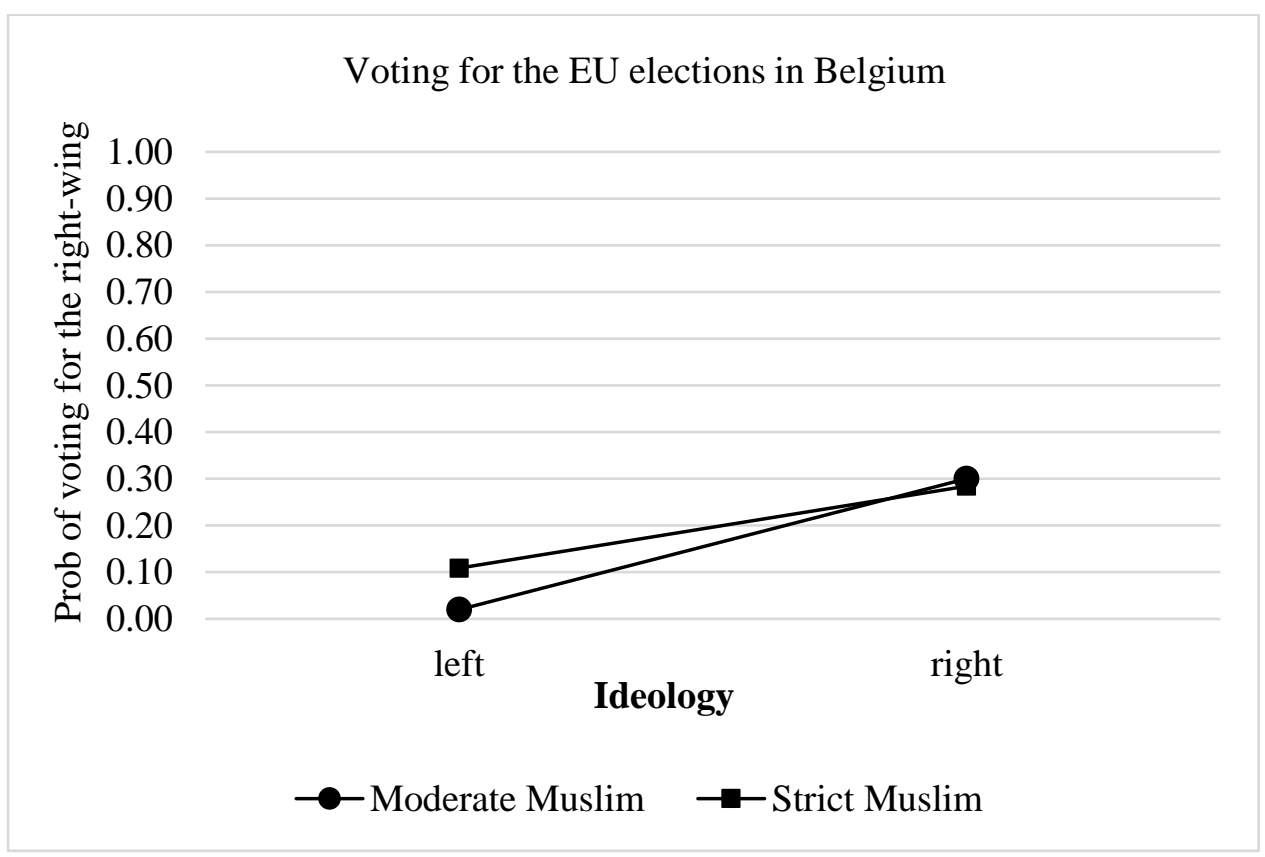

Figure $2 d$. Probability of voting for right-wing (vs left-wing) parties in the EU elections of Belgium as a function of Muslim identity content and left-right ideology 


\section{Supplementary Online Material}

\section{Robustness Checks for Logistic Regression}

Although the rule of thumb for logistic regression analysis is defined as 10 events (event defined by the smaller cell size in the binary outcome variable) per predictor (EPV), critical bias has been observed only with $5 \mathrm{EPV}$ and/or when the sample size is smaller than 250 (Bergtold et al., 2011; Ranganathan et al., 2017; Vittinghoff \& McCulloch, 2007). In our analysis, we had 12 predictors in the final step ( 6 control variables +3 typical predictors +3 additional predictors in the final model) and 9 predictors in the second step. When taking into account the smaller cell sizes in the binary outcome variables (i.e., voting for right vs. leftwing parties), the range for EPV is roughly between 5-7 for the final step, and between 6-9 in the second step (best in the election for Turkey and worst in the regional elections). Our sample size is larger than the recommended sample size, and the EPV is never smaller than 5, making type 1 error rate and bias highly unlikely. Moreover, as a further robustness check for the effects of Muslim identity content, ideology and their interaction, we entered them into the analysis with controls only (thus in total 9 predictors), and the results were stable.

Specifically, for voting for right-wing in Turkey, moderate Muslims were 2.5 time less likely to vote for right-wing $(b=-.90, S E=.29, p=.002)$ and ideology had no significant effects $(b=-.02, S E=.06, p=.742)$. For Voting in Belgium, Muslim identity content had no significant effects at the chamber $(b=.19, S E=.35, p=.590)$, region $(b=.28, S E=.35, p=$ $.429)$ and EU levels $(b=-.30, S E=.35, p=.385)$. Yet, ideology did have significant effects so that right-leaning were more likely to vote for right-wing parties at the chamber $(b=.41$, $S E=.08, p<.001)$, region $(b=.38, S E=.08, p<.001)$ and EU levels $(b=.39, S E=.08, p<$ .001). When the interaction was added to this model, the interaction was significant for voting in Turkey $(b=.33, S E=.12, p=.007)$ and in Belgium at the chamber $(b=.43, S E$ 
$=.19, p=.027)$, regional $(b=.34, S E=.18, p=.060)$ and EU levels $(b=.40, S E=.19, p=$ $.035)$.

References

Bergtold, J. S., Yeager, E. A., \& Featherstone, A. M. (2011). Sample size and robustness of inferences from logistic regression in the presence of nonlinearity and multicollinearity (No. 321-2016-11000).

Ranganathan, P., Pramesh, C. S., \& Aggarwal, R. (2017). Common pitfalls in statistical analysis: Logistic regression. Perspectives in Clinical Research, 8(3), 148.

Vittinghoff, E., \& McCulloch, C. E. (2007). Relaxing the rule of ten events per variable in logistic and Cox regression. American Journal of Epidemiology, 165(6), 710-718. 


\section{Analysis of Voting Behaviors in a Multivariate Model}

Although our aim was to repeat the same analysis across different voting outcomes in a stepwise fashion, it is also possible to test the same Dependent Variables in one model. In addition, we wanted to show the non-significant effects of perceived and group discrimination in these models for interested readers. Using Mplus 7, we first ran the final model using the four voting behaviors in the same analysis (See Table 1. SOM). Since it is not possible to do stepwise analysis for logistic regression in Mplus, we ran a separate analysis with the typical predictors of right-wing voting (See Table 2 SOM). The main results replicated across both models. Thus, while political inefficacy and deprivation were associated with higher likelihood of voting for the right in Turkey, these were associated with lower likelihood of voting for the right in Belgium. Authoritarianism similarly had a weak effect only observed for voting in Turkey. Muslim identity had a significant effect only in Turkey and ideology only in Belgium. Finally, the exploratory interaction between Muslim identity and ideology replicated but became marginal for voting at the EU level.

However, we should caution the readers that running multiple categorical DVs in the same model is not generally advised for logistic regression because such models are prone to problems of model identification due to hard-to-estimate correlations between categorical DVs (Buis, \& Jenkins, 2014). Mplus 7 allows for running logistic regression analyses with multiple DVs, however, it does not take into account estimates of potential correlations between categorical outcomes (unlike multivariate regression with multiple continuous DVs where the DVs are correlated).

Buis, M \& Jenkins, S (March, 2014). Responses to Stata discussion forum. Retrieved from https://www.statalist.org/forums/forum/general-stata-discussion/general/413670logistic-regression-with-more-than-one-dependent-variable, 
Table 1. SOM. Multivariate Logistic Regression for Voting: The Final Model

\begin{tabular}{|c|c|c|c|c|}
\hline & Vote TR & Vote BE C & Vote BE R & Vote BE EU \\
\hline Age & $-.24(.12)^{*}$ & $.30(.10)^{* *}$ & $.26(.11)^{*}$ & $.22(.10)^{*}$ \\
\hline City (Liege vs Antwerp) & $-.06(.07)$ & $.21(.07)^{* *}$ & $.20(.08)^{*}$ & $.18(.08)^{*}$ \\
\hline Gender (woman vs man) & $-.06(.08)$ & $-.17(.08)^{*}$ & $-.08(.09)$ & $-.29(.08)^{* * *}$ \\
\hline Higher secondary (vs middle school) & $-.23(.09)^{* *}$ & $.12(.11)$ & $.04(.01)$ & $-.01(.09)$ \\
\hline University (vs middle school) & $-.16(.08)^{*}$ & $-.00(.11)$ & $-.05(.10)$ & $-.20(.09)^{*}$ \\
\hline Generation (2nd vs 1st gen) & $08(.11)$ & $.13(.11)$ & $.22(.10)^{*}$ & $.24(.09)^{*}$ \\
\hline Political efficacy & $-.12(.07)^{\mathrm{d}}$ & $.21(.07)^{* *}$ & $.21(.07)^{* *}$ & $.23(.07)^{* *}$ \\
\hline Political deprivation & $.26(.09)^{* *}$ & $-.13(.09)$ & $-.09(.09)$ & $-.15(.09)^{\mathrm{d}}$ \\
\hline Authoritarian & $.16(.08)^{*}$ & $.12(.07)^{\mathrm{d}}$ & $.11(.08)$ & $.06(.07)$ \\
\hline Personal discrim & $-.17(.09)^{\mathrm{a}}$ & $-.02(.13)$ & $-.13(.15)$ & $-.13(.11)$ \\
\hline Group discrim & $.07(.10)$ & $-.16(.14)$ & $-.15(.15)$ & $-.06(.12)$ \\
\hline Mod vs Strict Muslims & $-.24(.08)^{* *}$ & $-.12(.09)$ & $-.09(.10)$ & $-.20(.09)^{*}$ \\
\hline Right-wing ideology & $-.14(.12)$ & $.28(.11)^{* *}$ & $.27(.11)^{*}$ & $.25(.10)^{*}$ \\
\hline Interaction: & & & & \\
\hline Muslim identity x ideology & $.24(09)^{* * *}$ & $.26(.13)^{*}$ & $.23(.13)^{\mathrm{c}}$ & $.24(.13)^{\mathrm{b}}$ \\
\hline $\mathrm{R}^{2}$ & .29 & .46 & .39 & .48 \\
\hline
\end{tabular}

\begin{tabular}{lllll}
\hline \multicolumn{5}{l}{ Table 2. SOM. Multivariate Logistic Regression for Voting: The Simpler Model } \\
\hline & Vote TR & Vote BE C & Vote BE R & Vote BE EU \\
\hline Age & $-.30(.12)^{*}$ & $.33(.13)^{*}$ & $.28(.14)^{\mathrm{a}}$ & $.18(.14)$ \\
City (Liege vs Antwerp) & $-.02(.08)$ & $.19(.09)^{\mathrm{a}}$ & $.17(.10)^{\mathrm{d}}$ & $.16(.10)$ \\
Gender (woman vs man) & $-.07(.08)$ & $-.24(.09)^{* *}$ & $-.14(.09)$ & $-.34(.09)^{* * *}$ \\
Higher secondary (vs middle school) & $-.24(.09)^{* *}$ & $.12(.26)$ & $.05(.10)$ & $.00(.10)$ \\
University (vs middle school) & $-.20(.08)^{*}$ & $-.03(.11)$ & $-.08(.10)$ & $-.12(.11)$ \\
Generation (2nd vs 1st gen) & $.05(.11)$ & $.12(.11)$ & $.20(.11) \mathrm{a}$ & $.12(.11)$ \\
Political efficacy & $-.13(.07)^{\mathrm{b}}$ & $.25(.07)^{* * *}$ & $.26(.07)^{* * *}$ & $.22(.07)^{* *}$ \\
Political deprivation & $.28(.04)^{* *}$ & $-.26(.09)^{* *}$ & $-.21(.09)^{*}$ & $-.29(.09)^{* *}$ \\
Authoritarian & $.12(.08)^{\mathrm{d}}$ & $.06(.10)$ & $.07(.11)$ & $-.01(.10)$ \\
Personal discrim & $-.13(.09)$ & $-.10(.12)$ & $-.20(.13)$ & $-.13(.12)$ \\
Group discrim & $-.01(.10)$ & $-.04(.14)$ & $-.05(.14)$ & $.02(.12)$ \\
$\mathrm{R}^{2}$ & .21 & .25 & .24 & .25 \\
\hline
\end{tabular}

Note: Table presents standardized regression coefficients (STDYX Standardization) 


\section{Individuals' Positions on Socio-cultural and Economic Issues as Separate Predictors}

In addition to the left-right ideology placement, we had a number of measures about people's positions on socio-cultural and economic issues. In this analysis, we aim to provide a more nuanced picture of the ways ideology might affect voting behavior.

Tapping into more socio-cultural issues, we had measures of acceptability of abortion laws, euthanasia for minors and gay couples' right to adopt children $(1=$ completely not acceptable to 5 completely acceptable). We created a composite score with higher scores indicating more acceptability of these issues $(\alpha=.64)$. Tapping into economic issues, we had measures of support for the provision of health care $(1=$ healthcare responsibility of the individual, not the government to $4=$ government should provide subsidized health care to everyone $)$ and regulation of businesses by the state $(1=$ business should be regulated to $10=$ business completely free).

First, we explored the correlations between these measures and the left-right ideology self-placement. Socio-cultural position was marginally significantly related to left-right ideology suggesting that those right-leaning were less likely to find these socio-cultural issues acceptable $(R=-.11, p=.046)$. Interestingly this score was more strongly related to their being a moderate Muslim (vs. strict) $(R=.25, \mathrm{p}<.001)$. Finally, we also looked at the correlations between their stance in socio-cultural issues and voting behaviors. Socio-cultural position was significantly related to voting in Turkey $(R=-.20, p<.001)$, so that those finding these issues more acceptable were less likely to vote for right-wing parties (AKP) in Turkey but it was not significantly related to voting in Belgium (all $p \mathrm{~s}>.200$ ). This suggests that among Turkish-Muslim Belgians their stance on socio-cultural issues is more related their Muslim identity, than their left-right ideology, and this explains why their stance in socio-cultural issue predicts their voting behavior in Turkey (but not in Belgium). 
As for their position on the economic issues, neither measure (healthcare, business regulations) was significantly correlated with left-right ideology (both $p \mathrm{~s}>.200$ ), with the positioning on socio-cultural issues (both $p$ s $>.200$ ), or with being moderate vs conservative Muslim (both $p$ s > .200). In terms of their associations with voting behavior, however, the more they supported government subsidized free health care for everyone, the less likely they were to vote for right wing parties in Belgium, at the chamber $(R=-.13, p=.017)$, and regional levels $(R=-.12, p=.038)$ (with a similar trend at the EU level, $(R=-.09, p=.097)$, but this was not significantly related to voting in Turkey $(R=-.00, p=.943)$. Finally, regulation of businesses was not significantly related to any voting behaviors (all $p$ s $>.200$ ), this we did not focus on this variable in the next round of analyses.

We ran logistic regression analyses in the same stepwise fashion as in the main analysis in the paper. In the third step, we added their stance on socio-cultural and economic issues in addition to their ideology and Muslim identity content. Table 3.SOM shows the results of these logistic analyses in the third step. Muslim identity content and their sociocultural position had significant effects on voting for right-wing in Turkey, so that moderate Muslims and those who find these issues more acceptable were less likely to vote for AKP. Their self-placement on left-right ideology and support for free healthcare had no significant effects. As for voting in Belgium at different levels, left-right ideology and support for free healthcare had significant effects, while Muslim identity content and sociocultural position had no significant effects. Their stance on the socio-cultural and economic issues explained $3 \%$ of the variance across different voting behaviors.

Finally, all the effects of the typical predictors of voting (autotomy, efficacy and deprivation) replicated in the second step of the analysis, as well as the interaction between Muslim identity content and left-right ideology in the final step of the analyses (The full results of these analyses can be requested from the corresponding author) 
Table 3. Logistic Regression for Voting Behaviors: Socio-cultural and economic dimensions of leftright ideology

\begin{tabular}{|c|c|c|c|c|c|c|c|c|}
\hline & \multicolumn{2}{|l|}{$\begin{array}{l}\text { Vote } \\
\text { Turkey }\end{array}$} & \multicolumn{2}{|c|}{ Vote Chamber } & \multicolumn{2}{|c|}{ Vote Regional } & \multicolumn{2}{|l|}{$\begin{array}{l}\text { Vote } \\
\text { EU }\end{array}$} \\
\hline & B (SE) & $\begin{array}{l}\text { Exp } \\
\text { (B) }\end{array}$ & B (SE) & $\begin{array}{l}\text { Exp } \\
\text { (B) }\end{array}$ & B (SE) & $\begin{array}{l}\text { Exp } \\
\text { (B) }\end{array}$ & B (SE) & $\begin{array}{l}\text { Exp } \\
\text { (B) }\end{array}$ \\
\hline Age & $\begin{array}{l}-0.05 \\
(.02)^{* *}\end{array}$ & 0.95 & $\begin{array}{l}0.06 \\
(.02)^{* *}\end{array}$ & 1.06 & $\begin{array}{l}0.04 \\
(.02) \mathrm{a}\end{array}$ & 1.04 & $\begin{array}{l}0.04 \\
(.02) \mathrm{b}\end{array}$ & 1.04 \\
\hline $\begin{array}{l}\text { City } \\
\text { (Liege vs Antwerp) }\end{array}$ & $\begin{array}{l}-0.62 \\
(.36) \mathrm{c}\end{array}$ & 0.54 & $\begin{array}{l}0.84 \\
(.42) \mathrm{a}\end{array}$ & 2.32 & $\begin{array}{l}0.69 \\
(.42)\end{array}$ & 1.99 & $\begin{array}{l}0.83 \\
(.42) \mathrm{a}\end{array}$ & 2.28 \\
\hline Gender (woman vs man) & $\begin{array}{l}-0.17 \\
(.32)\end{array}$ & 0.84 & $\begin{array}{l}-0.73 \\
(.38) \mathrm{a}\end{array}$ & 0.48 & $\begin{array}{l}-0.18 \\
(.37)\end{array}$ & 0.83 & $\begin{array}{l}-1.24 \\
(.38)^{* *}\end{array}$ & 0.29 \\
\hline $\begin{array}{l}\text { Higher secondary (vs } \\
\text { middle school) }\end{array}$ & $\begin{array}{l}-0.84 \\
(.36)^{*}\end{array}$ & 0.43 & $\begin{array}{l}0.41 \\
(.41)\end{array}$ & 1.51 & $\begin{array}{l}-0.02 \\
(.40)\end{array}$ & 0.98 & $\begin{array}{l}-0.24 \\
(.38)\end{array}$ & 0.79 \\
\hline $\begin{array}{l}\text { University (vs middle } \\
\text { school) }\end{array}$ & $\begin{array}{l}-0.54 \\
(.48)\end{array}$ & 0.58 & $\begin{array}{l}-0.30 \\
(.68)\end{array}$ & 0.74 & $\begin{array}{l}-0.79 \\
(.68)\end{array}$ & 0.45 & $\begin{array}{l}-1.93 \\
(.78)^{*}\end{array}$ & 0.15 \\
\hline Generation (2nd vs 1 st gen) & $\begin{array}{l}0.29 \\
(.38)\end{array}$ & 1.34 & $\begin{array}{l}0.60 \\
(.48)\end{array}$ & 1.82 & $\begin{array}{l}0.93 \\
(.49) \mathrm{a}\end{array}$ & 2.55 & $\begin{array}{l}0.99 \\
(.49)^{*}\end{array}$ & 2.7 \\
\hline Political efficacy & $\begin{array}{l}-0.39 \\
(.19)^{*}\end{array}$ & 0.68 & $\begin{array}{l}0.63 \\
(.23)^{* *}\end{array}$ & 1.87 & $\begin{array}{l}0.56 \\
(.23)^{*}\end{array}$ & 1.75 & $\begin{array}{l}0.68 \\
(.23)^{* *}\end{array}$ & 1.97 \\
\hline Political deprivation & $\begin{array}{l}0.39 \\
(.14)^{* *}\end{array}$ & 1.48 & $\begin{array}{l}-0.26 \\
(.17)\end{array}$ & 0.77 & $\begin{array}{l}-0.14 \\
(.18)\end{array}$ & 0.87 & $\begin{array}{l}-0.25 \\
(.17)\end{array}$ & 0.78 \\
\hline Authoritarian & $\begin{array}{l}0.63 \\
(.24)^{* *}\end{array}$ & 1.88 & $\begin{array}{l}0.48 \\
(.27) \mathrm{c}\end{array}$ & 1.61 & $\begin{array}{l}0.41 \\
(.27)\end{array}$ & 1.51 & $\begin{array}{l}0.27 \\
(.26)\end{array}$ & 1.31 \\
\hline Mod vs Strict Muslims & $\begin{array}{l}-0.85 \\
(.32)^{* *}\end{array}$ & 0.43 & $\begin{array}{l}-0.01 \\
(.39)\end{array}$ & 0.99 & $\begin{array}{l}0.00 \\
(.39)\end{array}$ & 1.00 & $\begin{array}{l}-0.66 \\
(.39) c\end{array}$ & 0.52 \\
\hline Right-wing ideology & $\begin{array}{l}0.03 \\
(.06)\end{array}$ & 1.03 & $\begin{array}{l}0.40 \\
(.08)^{* * *}\end{array}$ & 1.49 & $\begin{array}{l}0.37 \\
(.08)^{* * * *}\end{array}$ & 1.45 & $\begin{array}{l}0.39 \\
(.08)^{* * * *}\end{array}$ & 1.47 \\
\hline Socio-cultural position & $\begin{array}{l}-0.49 \\
(.20)^{*}\end{array}$ & 0.61 & $\begin{array}{l}-0.20 \\
(.23)\end{array}$ & 0.82 & $\begin{array}{l}0.00 \\
(.24)\end{array}$ & 1.00 & $\begin{array}{l}0.31 \\
(.23)\end{array}$ & 1.37 \\
\hline Free healthcare & $\begin{array}{l}-0.06 \\
(.22)\end{array}$ & 0.94 & $\begin{array}{l}-0.44 \\
(.22)^{*}\end{array}$ & 0.65 & $\begin{array}{l}-0.43 \\
(.22)^{\mathrm{a}}\end{array}$ & 0.65 & $\begin{array}{l}-0.44 \\
(.21)^{*}\end{array}$ & 0.64 \\
\hline Constant & $\begin{array}{l}2.1 \\
(.41) * * *\end{array}$ & 8.20 & $\begin{array}{l}-2.37 \\
(.48) * * *\end{array}$ & 0.09 & $\begin{array}{l}-2.48 \\
(.48)^{* * * *}\end{array}$ & 0.08 & $\begin{array}{l}-1.42 \\
(.42)^{* *}\end{array}$ & 0.24 \\
\hline Nagelkerke R2 & 0.24 & & 0.35 & & 0.28 & & 0.35 & \\
\hline
\end{tabular}

$* p<.05 * * p<.01^{\mathrm{a}} p<.06^{\mathrm{b}} p=<.07^{\mathrm{c}} p<.10$ 


\section{Voting Behavior of non-Muslim Turkish Belgians}

We focus on Muslim identity because Muslim identity it is an important, salient yet contested identity for Muslim minorities in Europe (Foner \& Alba, 2008) and a likely predictor of their political behavior (Fleischman et al., 2011, Phalet, Baysu \& Verkuyten, 2010). Thus, we limit the sample to those who identify as Muslim. In other words, it would be theoretically justified to look at how Muslim identity would affect the voting behaviors of those who self-identified as Muslim. However, we can look at whether voting behavior is determined by self-identification as Muslim. To this end, we created a dummy-coded variable comparing those who did not identify as Muslim vs those who did (\%15 vs. $\% 85, N=447)$. We ran binary logistic regression analyses controlling for the same variables (age, education, gender, generation, city). Turkish-Muslim Belgians were 11.5 more likely to vote for rightwing parties in Turkey compared to the non-Muslim Turkish Belgians $(b=2.44, S E=.47, p$ $<.001$ ) and it explained $12 \%$ of the variance in voting (nagelkerke $\mathrm{R}^{2}=.12$ ). When looking at voting for right-wing parties in Belgium at different levels, both Muslims and non-Muslims were less likely to vote for right-wing than left-wing parties in Belgium. While there was no difference for voting at the EU level $(b=-.01, S E=.38, p=.979)$, Muslims were twice less likely to vote for right-wing parties compared to non-Muslims at parliament $(b=-.62, S E=$ $.33, p=.063$, nagelkerke $\left.\mathrm{R}^{2}=.01\right)$ and regional levels $(b=-.71, S E=.35, p=.044$, nagelkerke $\mathrm{R}^{2}=.02$ ). However, one should be cautious interpreting these latter findings due to marginal significance levels and small cell sizes (both in the predictor and outcome variables). 